\title{
Penalties and Optimality in Financial Contracts: Taking Stock
}

\author{
Michel A. Robe* \\ Eva-Maria Steiger** \\ Pierre-Armand Michel***
}

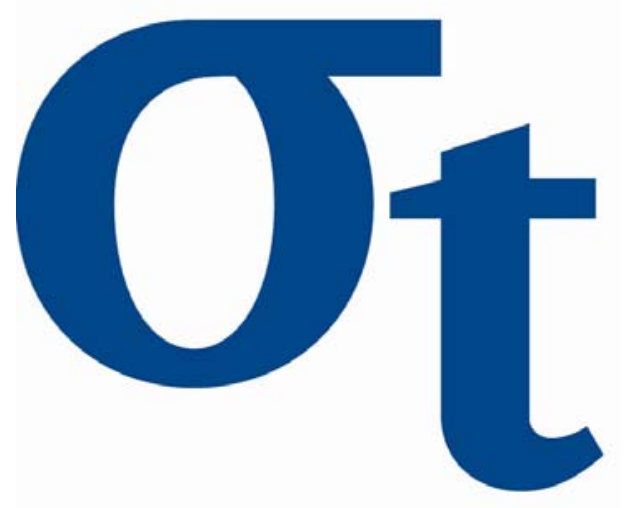

* Kogod School of Business, American University, Washington DC, USA

** Institut für Organisationstheorie, Humboldt-Universität zu Berlin, Germany

*** Ecole d'Administration des Affaires, Université de Liège and

Luxembourg School of Finance, Université de Luxembourg

This research was supported by the Deutsche

Forschungsgemeinschaft through the SFB 649 "Economic Risk".

http://sfb649. wiwi. hu-berlin.de

ISSN 1860-5664

SFB 649, Humboldt-Universität zu Berlin

Spandauer Straße 1, D-10178 Berlin

の)

$\nabla$

$(0$

m

느 


\title{
Penalties and Optimality in Financial Contracts: Taking Stock
}

\author{
Michel A. Robe* \\ Kogod School of Business \\ American University \\ 4400 Massachusetts Avenue, NW \\ Washington, DC 20016, U.S.A.
}

\author{
Eva-Maria Steiger
}

Walther-Rathenau Institut für Organisationstheorie

Humboldt Universität zu Berlin

Spandauer Straße 1

10178 Berlin, Germany

\author{
Pierre-Armand Michel \\ Ecole d'Administration des Affaires \\ Université de Liège \\ 7, Boulevard du Rectorat \\ 4000 Liège, Belgium \\ and \\ Luxembourg School of Finance \\ Université de Luxembourg \\ 209, Route d'Esch \\ L-1471 Luxembourg \\ Current Draft: February 2006
}

\footnotetext{
${ }^{*}$ Corresponding author. We thank Bernard Demonty, Dominique Demougin, Augustine Duru, Erik Lenntrop, Stéphane Pallage, David Reeb, Michèle Vanwijck, and participants to seminars at the Max Planck Institute of Economics (Jena) and American University, brownbags at the Norwegian School of Management (Oslo) and the Copenhagen Business School, and the 2006 Erasmus Workshop of the European Association for Law and Economics (Hamburg) for useful comments and suggestions. Michel and Steiger thank, respectively, Belgium's Fonds National de la Recherche Scientifique (FNRS) and the Deutsche Forschungsgemeinschaft (DFG, through SFB 649 "Economic Risk") for financial support. This paper was written in part when Robe was visiting McGill and George Washington Universities. Their hospitality is gratefully acknowledged, as is research support received as a Kogod endowed fellow at American University. The paper was finalized while Robe was visiting the U.S. Commodity Futures Trading Commission (CFTC). The views expressed in this paper are those of the authors only and do not, in any way, reflect the views or opinions of the CFTC or of its staff. The usual disclaimer applies.
} 


\title{
Penalties and Optimality in Financial Contracts: Taking Stock
}

\begin{abstract}
A popular view of limited liability in financial contracting is that it is the result of societal preferences against excessive penalties. The view of most financial economists is instead that limited liability emerged as an optimal institution when, in the absence of a clear limit on economic agents' liability, the development of some economic activities might have been thwarted. Viewing the institution from the perspective of optimal legal system design allows us to better understand the current debate on it.

We present a broad history of penalties in financial contracts to highlight the interactions between technology, legal environments, purpose of the financial relationship, and contractual provisions. We show that harsh monetary and non-pecuniary penalties are not mere relics from a bygone era and, at the same time, that limited liability is far from a recent institution. We then discuss trade-offs associated with legal mandates of either unlimited or limited liability, both for the contracting parties and for the rest of Society.

We identify two broad patterns. First, the toughness of liability rules and bankruptcy laws decreases as exogenous sources of uncertainty become relatively more important, and increases with the opportunity for moral hazard (related to diligence, risk taking, or deception). Second, bankruptcy laws become more lenient as the scope for labor specialization and the returns to human capital or entrepreneurship increase.
\end{abstract}

Key words: Limited Liability, Bankruptcy, Debt Bondage, Debtors' Prison, History.

JEL classification: G32, D82. 


\section{Introduction}

Two key questions in financial contracts are the range of incentives available to the parties and the conditions under which these incentives may be used. Perhaps most important in a loan contract, then, are the provisions that deal with the aftermath of default.

For more than four decades, legal scholars and financial economists have striven to rationalize the choice of liability regime by contracting parties, to explain why governments may elect to restrict that choice, and to assess the consequences of governmental interventions. In this paper, we focus on the literature, spawned by these efforts, that deals with defaulting private debtors. We provide a history, and discuss analyses, of the entire range of penalties imposed on individuals when they default on their own loans or when a corporation in which they have invested fails. We also contribute by collecting, in a single place, salient facts about the consequences of financial default in various nations, from Babylonian to modern times. This approach allows the reader to contrast the evolution of penalties over time with the lesser variation across nations in a given era. At the same time, it allows us to discuss topics such as the choice between monetary and non-monetary penalties, liability limits, reputational costs of default, and debt renegotiation. Finally, it helps explain the apparent convergence of both personal and corporate bankruptcy regimes in developed countries in the last twenty years.

Almost all societies restrict individual economic agents' freedom to contract. That is, the choice of penalties for default depends not only on the free will of the contracting parties, but also on the rest of society's philosophy regarding what constitutes an acceptable upper bound on agents' liability. We illustrate the diversity of such philosophies by reviewing the treatment of defaulting private debtors in various societies. We look at the consequences of default for individuals as such (Section 2) and for investors in corporations (Section 5). In both cases, we contrast legal systems that authorize harsh penalties - including sending failed borrowers to jail or even to the scaffold with others that mandate strict limits on the maximum liability for default.

A natural question is what would happen absent legal constraints. We therefore review the theoretical and empirical literatures that analyze the optimal choice of liability regime in private financial contracts. Again, we consider repayment promises by consumers or entrepreneurs (personal debts, Section 3) as well as the liability of investors in a defaulting corporation (Section 6).

Next, we turn to the impact of liability rules and bankruptcy laws in personal loan contracts (Section 4) and in corporate settings (Section 7). Because legal mandates regarding default penalties have consequences both for the parties to the contract and for society as a whole, we examine 
those consequences at the contracting and macroeconomic levels. We start with the relevant theoretical studies, discuss quantitative analyses, and review the empirical evidence. We conclude by summarizing the current law-and-economics debate on the optimality of limited liability rules.

We draw two broad conclusions from our analysis. First, both in practice and in theory, the toughness of liability rules and bankruptcy laws decreases with the relative importance of exogenous sources of uncertainty, and increases with the opportunity for moral hazard (related to diligence, risk taking, or deception). Second, bankruptcy laws become more lenient as the scope for labor specialization expands and as the returns to human capital or entrepreneurship increase.

Several recent treatises on limited liability (Noe \& Smith, 1997; Carney, 1999; Robe \& Michel, 2000), consumer finance (Hynes \& Posner, 2002), and bankruptcy (White, 2005a) are related to the present paper. We abstract from specific discussions of investors' liability for corporate torts (Carney, 1999) and from liability issues for workers or managers in corporate settings (Noe \& Smith, 1997). Instead, we focus on the history and analysis of penalties for default on private debt, and relate those to the analysis of similar penalties in other areas of economics (e.g., development economics). Establishing this linkage is especially valuable for empirical studies of limited liability, given their relative scarcity in the financial area. Hynes \& Posner (2002) provide an overview of all major U.S. consumer finance laws, including personal bankruptcy laws, and discuss these regulations in light of the economics literature on consumer credit markets. In contrast, we focus on liability rules and analyze the interactions between legal environment, purpose of the credit, and contractual provisions. Like White (2005a), we look at the consequences of both personal and corporate defaults. Her main focus is on bankruptcy. Ours is on the fate of individual borrowers or investors following default.

With the exception of Robe \& Michel (2000), the discussion in all the above papers is motivated mainly by current U.S. laws. A key contribution of our study is its consideration of differences in liability rules across time and space. We also review the evidence on recent changes in consumer bankruptcy and investor liability regulations in developed countries, and discuss rationales for the apparent convergence of these rules. Finally, we extend Robe \& Michel (2000) along many dimensions. In particular, we cover consumer debt contracts and personal bankruptcy; debt renegotiations; and the effect of financial relationships' duration on the choice of penalties and on the impact of legal liability rules. We also discuss empirical and quantitative studies of the importance of liability rules and bankruptcy laws and of their implications for economic agents' welfare.

The article proceeds as follows. The first half of the paper deals with personal debts; the second half deals with investors in corporations. Each part is divided into three sections covering historical 
aspects (Sections 2 and 5), optimal contracting (Section 3 and 6), and legal mandates (Sections 4 and 7). Section 8 concludes and provides suggestions for further research.

\section{The law and defaulting individual borrowers}

Distinct societies may develop under dissimilar sets of circumstances. Their social norms, customs and laws may consequently differ. At first sight, the evolution of penalties for default over time is indeed striking. A closer look, however, reveals surprising similarities between default penalties in comparable environments, even in very different eras.

\subsection{The duty to repay}

Paying off one's debts is typically viewed as a moral obligation. This duty is reflected in the beliefs associated with many religions. Indeed, while creditors are sometimes urged to be lenient, ${ }^{1}$ the debtor's duty to repay is reinforced by the threat of dire consequences in this world or the next. ${ }^{2}$ However, when religious edicts and customs are not the only set of formal rules governing people's lives, or when incentives associated with the afterlife and the social stigma associated with default are not sufficient to elicit proper behavior, secular legal rules must fill the gaps.

In some cases, the legislator gives contracting parties strong incentives to fulfill their obligations. An extreme example is early Roman law: the third of the Twelve Tables (ca. 451 BC) let private creditors seize their debtors unless they made a settlement and, after a sixty-day grace period, put them to death or sell them into slavery "across the Tiber," i.e., abroad. In many other ancient societies, penalties allowed by the legal system were also drastic: while the failed debtor may not always have had to fear death, he still faced involuntary servitude. In Babylonian times, for instance, loans were guaranteed by the person of the debtor or one of his kin (Johns, 1910). A

\footnotetext{
${ }^{1}$ For example, the Jewish Bible provides for forgiveness for debts owed by poor Jews every seven years (Lev 25:3543, Deut 15:1-2). The New Testament exhorts Christian creditors to forgive debtors who cannot pay (Mt 18:23-35). The Koran likewise asks of creditors that they extend repayment or even forgive debts when their debtors are facing dire circumstances (Qur'an II:280; see also Seniawski (2001)).

${ }^{2}$ Early Hindu law, for instance, permitted the killing of a defaulter and the enslavement of his wife (Kilpi, 1998). For Hindus, defaulting is also a transgression and failed debtors' prospects in the next life are dim (Chatterjee, 1971). In Judaism, despite a stipulation that poor people's debts be periodically forgiven, the moral obligation to repay one's debt remains (Efrat, 1998). Christians have the same obligation (Rom 13:7). In Islam, "all agreements must be observed, since God is a witness to any contract entered by individuals" (Efrat (1998); see Qur'an II:282).
} 
similar principle is found in traditional Chinese society. ${ }^{3}$ Various parts of the books of Deuteronomy and Leviticus in the Old Testament bear out that Jewish law in Moses' time, like its Mesopotamian forebears, allowed for debt bondage. In pre-Solonian Athens, likewise, failure to pay off private debts that had been secured on a free person led to the loss of both freedom and the right to the fruits of one's labor (Kilpi, 1998). Even in early Roman practice, the defaulted debtor was often made to work for his creditor until the fruits of his labor had repaid the debt (Vigneron, 1998).

The Middle Ages and the Renaissance of Europe saw the emergence of alternatives to debt bondage. In Venice, for instance, a law enacted in 1195 gave creditors the right to seize not just the debtor's assets but also one third of his future income, until all claims were satisfied (Besta \& Predelli, 1901). Still, in most places, creditors' right to seize their debtors remained. The purpose of this right, however, had changed: seizure did not typically result in bondage to the lender any more. Rather, it was now principally a prelude to recalcitrant debtors' sojourn in another institution that had become prevalent: the debtors' prison. ${ }^{4}$

A key distinction between bondage and debtors' prison is that remanding a debtor to prison provides no utility to the creditor per se (unless he is sadistic). ${ }^{5}$ Instead, imprisonment acts principally as a way to prompt payment. ${ }^{6}$ In contrast, forced servitude can be viewed not only as a punishment for perceived misconduct (to wit, debt bondage and slavery were likely alternatives to death in early Roman law) but, in addition, as a means to compensate the creditor.

London's Fleet Prison, one of the oldest English jails whose name Charles Dickens has made famous worldwide, held reluctant or unfortunate debtors as early as 1352 (Brown, 1996). ${ }^{7}$ In Eng-

\footnotetext{
${ }^{3}$ The legal tradition and ethical concept of "father's debt to be paid by the sons" prevailed in China until reforms under the Qing dynasty at the beginning of the twentieth century (Zhou, 1995).

${ }^{4}$ Instances of debt bondage could still be found, though. As late as the seventeenth and the eighteenth centuries, for example, a large fraction of white settlers in Britain's American colonies came as indentured servants or bondsmen (Smith, 1947; Christianson, 1996; Grubb, 2003). In 1795, a New Jersey act - purporting to provide relief to insolvent debtors - mandated that the latter not be released from jail unless they were willing to "make satisfaction of [their] debts by servitude for up to seven years." That provision was not repealed until 1819.

${ }^{5}$ In England, incarceration could even be costly for the creditor, as he was responsible for the provision of "bread and water" to his jailed debtor. In practice, though, this obligation was consistently ignored (Babington, 1971).

${ }^{6}$ The general squalor found in prisons at the time was a strong additional incentive to avoid or get out of jail (Babington, 1971; Mann, 2003; Pugh, 1968). When these threats were deemed insufficient, some lawmakers used even harsher non-monetary punishments. In the U.S. state of Pennsylvania, for example, a 1785 law mandated public flogging and the cutting of an ear for deadbeats (Pomykala, 1997).

${ }^{7}$ Private debtors, that is. Spending time at the Fleet, which is first referred to in 1197 and was probably at least
} 
land, seizure could take place as soon as the debtor defaulted and release was typically conditional upon settlement of the debt. ${ }^{8}$ In France, the contrainte par corps or prison pour dettes was turned into a general means to coerce payment by the Ordonnance of Moulins in 1673 (t'Kint, 1991). Comparable methods were in use by then throughout Europe. For example, Antwerp lenders to Elizabeth I in the mid-sixteenth century would have been entitled to seize, in the event that she had defaulted, not only the goods but also the persons of the English merchants who had guaranteed the loans contracted by their queen (Outhwaite, 1968; Kohn, 1999b).

In the seventeenth and eighteenth centuries, debtors' prisons flourished. ${ }^{9}$ The gaols of Italian states and cities, such as the Malapaga carcere in Genoa, detained debitori insolventi throughout that period. In 1716, more than one percent of the population of England and Wales was in prison for debt (Babington, 1971). The institution's reach there was wide-ranging: a list of the Fleet Prison's pensioners at the time would have included not only the perennially downtrodden but also the fallen mighty. ${ }^{10}$ British colonies in the Americas, and later the newly independent United States, imitated and sometimes outdid the example set by the home country (Christianson, 1996).

Debtors' prisons remained a pillar of financial relationships in many countries well into the nineteenth century. ${ }^{11}$ Their widespread use until quite recently illustrates that threatening harsh

a century older (Brown, 1996), had been a bogy for the Crown's debtors since the middle of the thirteenth century (Pugh, 1968). Debts to the state, as well as payments between public entities, are beyond the scope of our paper.

${ }^{8}$ In a famous example, William Penn, who had earlier founded the New World colony of Pennsylvania, was in custody at the Fleet for nine months in 1708 until he had settled his debts (Peare, 1956). In the young United States, Robert Morris, one of the signers of the U.S. Declaration of Independence and a former U.S. Senator, was imprisoned for debt for more than three years. And Nathaniel Peabody, twice a delegate to the Continental Congress, stayed in a debtor's prison for about twenty years as his debts remained unpaid (U.S. Congress, 1999).

${ }^{9}$ The harshest of punishments had not disappeared entirely - death could still be meted out in the odd case. In France, Voltaire notes in his Dictionnaire Philosophique (1764) that fraudulent bankrupts had still suffered the penalty of death in the states of Orleans, under Charles IX, and in the states of Blois in 1576 (though these two edicts, renewed by Henry IV, were admittedly "merely comminatory"). The English bankruptcy law of 1705, likewise, stated that an uncooperative bankrupt who was defrauding his creditors could be put to death - although records indicate that only five debtors were put to death during the 115 years this provision was in effect (Tabb, 1995).

${ }^{10}$ The fact that wealthy individuals could be, and were, jailed for debt is consistent with evidence that the rich were frequently sued over breaches of credit contracts, not only by the well-off but also by the poor (Muldrew, 1993).

${ }^{11}$ London's Fleet was not closed until 1842 and Genoa's Malapaga, not until 1850. Further confirmation that the practice was still an integral part of life at the time can be found in the works of such literary giants as Balzac and Dickens, which are peppered with references to individuals jailed over unpaid debts. Famous people were still among those being jailed. To wit, after encountering financial difficulties following the earlier deaths of her husband and of 
penalties to coerce the payment of private debts was not solely the purview of ancient legal systems. By the mid-1800's, however, pressures that had been building to contain the excesses of debtors' prisons eventually led to their demise in most countries. U.S. states banned them during the depression that followed the Panic of 1837 (Pomykala, 1997). England and Wales abolished debtors' prison for private debts in 1869 (Tabb, 1995). In states soon to become part of the German Empire, leibliche Schuldhaftung was taken off the books in 1868 (Erler, Kaufmann, \& Stammler, 1971). France followed suit in 1871, and Italy in 1876 (di Martino, 2005).

\subsection{Debt relief and personal bankruptcy}

There now exists a worldwide consensus to make illegal the most ruthless methods of forcing compliance with the terms of loan contracts. Virtually all countries have several decades agreed that failed debtors should not be put to death or tortured, and that slavery and debt bondage should be banned. These commitments are enshrined in various charters and conventions of the United Nations (UN). ${ }^{12}$ By contrast, it is only in the last two decades that some convergence has taken place on how long-lasting the legal consequences of default should be.

Historically, most legislators have recognized inherent differences between commercial loans, meant to finance trade or risky investments, and consumer loans. Whereas in many countries there was until recently no way out of debt for delinquent non-commercial borrowers, commercial borrowers have often been treated more leniently. This subsection focuses on historical experiences with personal debt relief and bankruptcy. Institutions specifically designed to limit entrepreneurial liability for debts incurred in commercial ventures are discussed in more detail in Section 5 .

Legislators have also had to struggle with whether, and how, credit and bankruptcy laws should differentiate between "responsible" borrowers (those viewed as the victims of bad luck) and "culpable" bankrupts (those viewed as recklessly overextended, deficient in their efforts to repay, or plain dishonest). In ancient Babylon, while the Code of Hammurabi (c. 1780BC) generally called for bondage in case of default, it allowed for debt relief when the inability to pay was due to events beyond the debtor's control. ${ }^{13}$ In contrast, the nexum contract in republican Rome, whereby the

Lord Nelson, Lady Hamilton spent time in debtor's prison with her daughter in 1812 (Sinoué, 2002).

${ }^{12}$ The UN's 1948 Human Rights Charter prohibits slavery. Its Convention Concerning the Abolition of Forced Labor makes debt bondage illegal: out of 191 member countries, 165 have ratified it since 1957. And, 154 countries have ratified the U.N.'s 1966 International Covenant on Civil and Political Rights, whose eleventh article prohibits imprisonment merely on the ground of a person's inability to fulfil a contractual obligation.

${ }^{13}$ See, e.g., Article 48: "If anyone owe a debt for a loan, and a storm prostrates the grain, or the harvest fail, or the 
debtor agreed to be seized by the lender in case of default, left no room to ill luck - but was banned in the fourth century BC because of abuses (Vigneron, 1998). Roman principles continued to be applied for many centuries in the Byzantine empire under the Justinian code (534AD).

In the Middle Ages of Europe, the Roman view lived on and default was again seen as misdeed rather than misfortune. In the thirteenth century, sanctions such as banishment or even the death penalty were the norm for defaulting merchants in the Italian cities of Siena and Vercelli (Pontani, 2004). The unforgiving legislations that originated in the medieval Italian towns were used in much of Western and Northern Europe. In England, for example, the first bankruptcy laws (1542/43, 1571, 1604 and 1624) codified very harsh penalties for failed borrowers, regardless of circumstances.

Almost all medieval bankruptcy laws applied only to traders; non-traders faced ordinary laws. ${ }^{14}$ These laws treated defaulting debtors as quasi-criminals (Tabb, 1995). It is only in the eighteenth century that England innovated by rediscovering the possibility of offering some leniency when default could be attributed due to ill luck. At the time, all bankrupts - regardless of circumstances - still faced grim fates across much of Europe and the New World. They were pilloried in France, for example. In England, meanwhile, the 1705 Statutes of Queen Anne instituted the possibility of discharge of debt for borrowers whose pre-default behaviors conformed to a list of good-conduct standards (whereas, in theory at least, fraudulent defaulters faced the death penalty).

Granted, the idea of a debt discharge is much older. The Code of Hammurabi limited debt bondage to three years. ${ }^{15}$ Other early examples are the forgiveness of debts owed by poor Jews, mandated every seven years by the Jewish Bible (Lev 25:35-43, Deut 15:1-2), and the Jewish Jubilee (Rosenberg \& Weiss, 2001). ${ }^{16}$ Even in the Middle Ages, at the same time that harsh penalties were

grain does not grow for lack of water; in that year he need not give his creditor any grain, he washes his debt-tablet in water and pays no rent for this year." (Johns, 1910)

${ }^{14}$ See, e.g., di Martino (2005). One exception is found in the Siete Partidas, a collection of laws enacted in 1342 by Alfonso X of Léon and Castille, whose provisions on debt collection applied to both commercial and non-commercial borrowers (Scheppach, 1991). Another exception is the first English bankruptcy statutes of 1542/43, which did not treat traders differently from others either (a dichotomy was restored after 1571 - see Muro (2005)).

${ }^{15}$ See, e.g., Article 117: "If any one fail to meet a claim for debt, and sell himself, his wife, his son, and daughter for money or give them away to forced labor: they shall work for three years in the house of the man who bought them, or the proprietor, and in the fourth year they shall be set free" (Johns, 1910).

${ }^{16}$ What makes these debt releases unique is that they were economically-motivated. Other contemporaneous uses of generalized debt releases were political, often to curry the favor of a constituency at home or to win over parts of the population in recently conquered territories. In such clean slate proclamations, the ruler or the conqueror would decree that "any land sold because of economic distress (be) returned to its original owners, anyone forced 
being meted out in most locales, the idea of discharge re-emerged in Spain. Specifically, the Siete Partidas codification of 1342 limited debt collection to the debtor's assets and prescribed that, once bankruptcy proceedings had ended, old debt could no longer be called (Scheppach, 1991).

Nevertheless, until the nineteenth century, insolvency and bankruptcy laws were typically very harsh and only merchants were seen as worthy of any bankruptcy procedure (Tabb, 2005). The United States is therefore exceptional in long having had very pro-debtor bankruptcy statutes for all borrowers (White, 1996; OECD, 1998).

The first U.S. bankruptcy law, in 1800, was lifted straight from the contemporary English law (Skeel, 2001). Both applied only to merchants and were creditor-friendly. Debtors could not initiate the bankruptcy proceedings. Since 1898, however, even non-commercial U.S. debtors have been able to file for personal bankruptcy, ask that some or all of their debts be dismissed, see their request granted, and move on with their lives. ${ }^{17}$ Depending on the state in which they live, and despite a significant reform enacted in October 2005 (Jeweler, 2005), it is even possible for bankrupt individuals to retain considerable property while discharging their debts (White, 1998b, 2005a).

An important objective of the debtor-friendliness of these U.S. personal bankruptcy regulations is to avoid distorting the debtor's future economic performance. As the U.S. Supreme Court stressed in an influential ruling (Local Loan Co. v. Hunt, 1934), the "bankruptcy discharge gives to the honest but unfortunate debtor (...) a new opportunity in life and a clear field for future effort." Without debt discharge, "from the viewpoint of the wage-earner, there is little difference between not earning at all and earning wholly for a creditor."

In sharp contrast, it took till the late 1990's for many more countries to move their legal codes away from viewing bankrupts as offenders and to introduce rules for consumer debt discharge. Until a few years ago, failed debtors outside the United States found it virtually impossible to shed the obligation to repay their creditors. In fact, many countries used to impose additional monetary and non-monetary penalties on failed debtors. The latter could lose retirement benefits (e.g., Belgium), be banned from managing companies or carrying out entrepreneurial activities (e.g., Australia, France, United Kingdom), or incur civil liability and possible criminal penalties (e.g., Germany).

into servitude by debts (be) liberated, and back debts (be) canceled" (Rosenberg \& Weiss, 2001). In modern times, debt release was again used as a political tool when various U.S. states such as Texas instituted generous homestead exemption laws to attract settlers (Goodman, 1993; Hynes, Malani, \& Posner, 2004).

${ }^{17}$ American debtors have enjoyed this right continuously since the U.S. Congress passed the Nelson Act of 1898. On two previous occasions, federal bankruptcy codes that were very debtor-friendly had been passed (in 1841 and 1867), but those were repealed (in 1843 and 1878, respectively) - see, e.g., Tabb (1995) and Pomykala (1997). 
Finally, laws traditionally treat fraudulent debtors more harshly than the merely hapless ones. Hence, to the extent that many bankruptcy regimes used to effectively classify most bankruptcies as fraudulent, they were harsher than regimes with a narrower interpretation of fraud.

In the case of consumers, most legal systems used to simply rule out any possibility that they might get their debts discharged. In countries where a discharge was at all possible, consumers who had filed for bankruptcy had to wait several years for the release to take place (two or three years in the United Kingdom, and up to ten years in Japan, for example (Martin, 2005)) and typically had to surrender some of their post-bankruptcy earnings to their creditors.

Today, though, the majority of industrialized countries have regulations that offer consumers a way out of debt. In the European Union (EU), where default rates have risen considerably amidst increased availability of credit (Koesters, Paul, \& Stein, 2004), most governments recently introduced regulated debt release procedures for non-merchant debtors. ${ }^{18}$

The common idea behind these new bankruptcy or insolvency laws, as well as behind the 2005 U.S. reform, has been to allow debt release while still encouraging a responsible use of credit by placing significant obstacles before a discharge can be granted. Though the specific prerequisites for a release differ across individual countries, two common tools are the seizure of current assets above a certain threshold and the garnishment of future income for a predetermined period. ${ }^{19}$

\footnotetext{
${ }^{18}$ Denmark started the process in 1984. It instituted a debt release procedure for "hopelessly indebted" debtors that later served as a model for other Scandinavian countries, with Finland, Norway and Sweden following suit between 1992 and 1994 (Niemi-Kiesilainen, 1997). In France, the "Loi Neiertz" came into effect in 1990 (Kilborn, 2005). It served as a model for Belgium in 1999 and Luxembourg in 2001 (Kilborn, 2006a). In Austria, legislation providing for consumer debt release was enacted in 1994 (Holzhammer, 1996). In England, substantial reforms were carried out in 1990 and again in 2004. Germany started allowing for consumer-debt discharge in 1999 (Steiger, 2005b). Similar regulations were introduced in the Netherlands in 1998 (Kilborn, 2006b). In Italy, regulations for consumer debt discharge are only being discussed - and the current insolvency legislation still concerns only merchants.

${ }^{19}$ The garnishment period varies widely across countries. In the U.K., the waiting period before bankruptcy has been shortened to one year for the majority of cases (Brockman, 2004). In Germany, debt discharge is conditional on a six-year period of good conduct (Kilborn, 2003). Sometimes, the duration is not set in stone. In Canada, it varies between three and five years and is contingent on creditor approval (McGregor, Klingander, \& Lown, 2001). In France, a committee decides upon each case and proposes a payment plan with a duration of up to ten years (since 2004, the most overextended consumers can be referred by the court to a procedure of personal recovery - similar to U.S. Chapter 7). In Austria, the length of the period of good conduct is contingent on the creditor's satisfaction rate (Bigus \& Steiger, 2002). In the United States, (relatively) better-off bankrupts are now barred from a Chapter 7 discharge and must reorganize under the revised Chapter 13, with a repayment period of five years (Jeweler, 2005).
} 
Debt counseling is often mandated. Of course, apart from these monetary and non-monetary legal penalties, there also remain other costs associated with bankruptcy - such as the harm to the future acquisition of credit and the stigma associated with being bankrupt.

In sum, a significant amount of legal convergence has taken place in the last two decades. In the United States, where many academics and policy makers had been questioning the personal bankruptcy law's generosity towards debtors (Wang \& White, 2000), reforms in 1984, 1994 and 2005 have made it harder for individuals to shed debts. In Europe, harsh insolvency regimes were widely seen as having adverse consequences on the local economies (OECD, 1998). They have been softened, and consumer bankruptcy procedures have been introduced. Other countries, especially in Asia, have followed suit or are likely to adopt middle-of-the-road systems (Martin, 2005).

Perhaps the largest remaining difference across countries, then, stems from the social perception of bankruptcy. On the one hand, much has been made of a perceived greater acceptance of default over the course of the last two decades in the United States (Calder, 2001; Fay, Hurst, \& White, 2002) and in Europe (Efrat, 1998, 2002). On the other hand, in societies where default is particularly stigmatized, failed borrowers may commit suicide. ${ }^{20}$ West (2003) suggests that the recent introduction of a consumer debt release regulation may have helped to ease the high suicide rates in Japan. Still, the fact that social stigma remains an issue in some countries is best illustrated by the fact that, in Asia, many distressed borrowers still resort to suicide rather than file for the bankruptcy protection to which they are legally entitled (Martin, 2005).

\section{Individual borrowing and liability regime}

An individual can use credit to afford a house, buy consumer durables, or simply smooth consumption over periods. Equally, credit may enable an individual to finance education or an entrepreneurial project. In this section, we first look at theoretical analyses of the optimal choice of borrower liability in case of default. Noting that most legal systems regulate the maximum such liability, we then explore the reasons for such rules and the economic rationales behind the design of regulated debt release procedures.

\footnotetext{
${ }^{20}$ In Thomas Mann's novel Felix Krull, for example, the German protagonist's father commits suicide due to the social marginalization following the failure of his sparkling wine business.
} 


\subsection{Optimal liability choice in personal credit contracts}

It is well-known from contract theory that, if an agent's unobservable actions affect the range of values that can be taken by an observable stochastic variable, then the first-best may be attained as long as sufficiently harsh penalties can follow undesirable outcomes. Even when no observable variable's support depends on the agent's actions, the threat of harsh punishments can help improve efficiency. To illustrate this idea, consider in turn several simple agency models of personal financing. In the first two (one with hidden outcomes, the other with hidden actions), harsh penalties incentivize debtors to work diligently towards compliance and enable them to credibly commit to repayment. In the third model, penalty choices act as costly signals or screening devices that alleviate ex-ante informational asymmetries.

First, suppose that an individual needs funding but outside investors face moral hazard, in that they cannot costlessly observe the cash-flows out of which they will be repaid. Then, the optimal financing contract corresponds to straight debt combined with auditing ("monitoring") in case of default (Townsend, 1979; Gale \& Hellwig, 1985). ${ }^{21}$ Alternatively, if there is no legal constraint on the penalties that can be meted out to defaulting borrowers, then straight debt contracts may be secured via penalties such as debtors' prison (Diamond, 1984) or the forfeiture of (possibly non monetary) collateral (Lacker, 2001). Using non-monetary incentives (such as debtors' prisons) instead of auditing can even be more efficient in some circumstances (Welch, 1995).

Second, consider an environment in which the financier can costlessly observe realized cash-flows but cannot monitor the effort expended by the cash-constrained borrower to generate these cashflows. Such a framework is qualitatively equivalent to the Mirrlees-Holmström moral hazard model with ex-ante action choices. Mirrlees (1976) argues that the properties of the optimal contract in that environment could be affected by exogenous limits on penalties. Robe (2001) shows numerically that such limits are in fact always binding for reasonable parameterizations. What is more, under the common assumption that borrowers exhibit constant absolute risk aversion, debt bondage is the optimal penalty for default in that model - even if it is the risk-averse borrower who chooses the terms of the contract to maximize his expected utility.

Third, if lenders cannot directly assess borrower's ability to repay, borrowers are likely to agree to harsh default penalties in order to signal their ability (Rea, 1984; Aghion \& Hermalin, 1990)). In related papers, Bester $(1985,1987)$ and Besanko \& Thakor (1987a, 1987b) rationalize collateral

\footnotetext{
${ }^{21}$ Precisely, the optimal contract involves randomized monitoring. Boyd \& Smith (1994), however, show numerically that deterministic monitoring entails negligible deadweight losses.
} 
requirements in environments where screening is needed..$^{22}$

The above results show that consumers and entrepreneurs may optimally choose unlimited liability or precommit to harsh penalties. A natural question is whether environments exist in which borrowers and lenders would both prefer relatively lenient penalties for borrower default.

The answer depends on whether markets are complete. Dubey, Geanakoplos, \& Shubik (1990, 2005), Zame (1993), and Araujo, Madeiro, \& Pascoa (1998) examine default in the context of general equilibrium models. In these closely related models, agents are heterogenous, defaulters are penalized in terms of direct disutility, and bankruptcy is strategic in that a borrower defaults if his marginal utility of income in a state of nature exceeds his marginal penalty for defaulting in that state. Assets are modeled as pools: hence, lenders only need to recover their investments on average rather than from any given individual. If markets are incomplete, Dubey et al. show that the optimal default penalty is high enough that not everyone defaults but is low enough to encourage some strategic default. In a single-good version of the model, Zame (1993) shows that an improvement in efficiency may be obtained by allowing agents to enter into contracts that they will be able to execute with high probability but not with certainty. In contrast, when penalties for default are infinite, agents are deterred from entering into such contracts.

\subsection{Why individual debt release regulations and limited liability rules?}

Most legal systems today limit the extent to which an individual may pledge himself. Such bounds can inhibit consumers' access to credit and entrepreneurial financing options. Equally, though, such limits can make borrowers better off. Rea (1984) and Aghion \& Hermalin (1990) show that, absent mandatory debt releases, low-risk borrowers may commit to excessive default penalties in order to signal their quality. Legal bans on arm-breaking and personal bankruptcy regulations prevent such "oversignalling," and make possible pooling debt contracts that leave both low- and high-risk borrowers better off. A related argument in favor of personal bankruptcy protections is that they provide insurance to risk-averse borrowers against bad income realizations (Rea, 1984).

Regulated debt releases can also deter opportunistic or inefficient behaviors by lenders. First, if lenders must pay to verify borrowers' claims regarding how much is available to repay the loans but can costlessly impose non-monetary penalties on any defaulting borrower, then legal bankruptcy protections may be optimal. Without them, lending would never take place because borrowers know that it would always be optimal ex-post for lenders to punish them indiscriminately rather

\footnotetext{
${ }^{22}$ See Coco (2000) for a detailed review of the literature on collateral.
} 
than monitor (Welch, 1995). Second, in the absence of debt release regulations, creditors have incentives to race for the borrower's assets at the first sign of trouble. This phenomenon is often observed in corporate bankruptcies (White, 2005a). Third, Posner (1995) shows that mandating a non-waivable right to discharge debts in bankruptcy counterbalances consumers' temptation to borrow (and banks' incentives to lend) excessively under the protection of the welfare system. He assumes that governments want to both protect free markets and reduce poverty. In a free market, however, the existence of a welfare system leads to excessive risk-taking. Hence, laws that prohibit debtors from securing credit by pledging future assets as collateral (or by accepting astronomical interest rates) are desirable, because they help contain the costs of providing a social safety net.

A key efficiency argument in favor of regulated debt releases is that they also help preserve incentives to work hard in the legal economy. Individuals overburdened with debt are likely to defect to the grey economy or work less - or even quit working and live on welfare instead (Graver, 1997). In societies where default is particularly stigmatized, failing borrowers may commit suicide. These observations argue for an immediate debt discharge. In anticipation of a debt release, however, debtors may be tempted to act strategically. Steiger (2005b) argues that this fundamental tension is at the heart of any bankruptcy procedure. Once a consumer incurs more debt than she can ever hope to pay back, she will reduce her effort level because increases in wage income go to her creditors. Thus, to ensure productivity after the debtor becomes insolvent, some form of debt relief is necessary. But before she borrows, the availability of debt relief reduces her incentive to work and her ability to borrow. Effort is reduced, because insolvency is less painful; and credit is more expensive, because creditors expect to receive less should the debtor file for bankruptcy.

\subsection{Optimal design of personal bankruptcy regulations}

Consumer bankruptcy laws should aim at unhampered economic performance, but ex-ante and ex-post efficiencies are intrinsically in conflict. Scholars have recently started analyzing the ability of existing laws to balance those two considerations, and suggesting improvements.

\subsubsection{Ex-ante incentives}

Legally-mandated debt-releases make up an important backdrop to credit contracts and affect an individual's decisions at several stages - prior to signing the debt contract; during the life of the contract; and, finally, in the event of distress. 
The decision whether or not to enter into a credit contract depends on the default provisions. When the law allows these provisions to be harsh, individuals may simply refrain from borrowing (Zame, 1993). In that sense, the right to file for bankruptcy protection provides insurance against bad income realizations (Rea, 1984; Adler, Polak, \& Schwartz, 2000). This insurance protection is even more valuable if debtors incorrectly assess the scope of their commitments and over-borrow (Adler et al., 2000; Bar-Gill, 2004). At the same time, lenders' decision to extend credit is also affected by the generosity of the bankruptcy regulations (Gropp, Scholz, \& White, 1997).

During the life of the credit contract, though, the certainty of bankruptcy protection reduces the debtor's work incentives, which in turn increases the likelihood that she will face financial distress. Adler et al. (2000) characterize analytically the trade-off between containing such moral hazard and preserving the insurance benefits of a possible fresh start. They then analyze how institutions such as collateral requirements and loan reaffirmations affect this trade-off.

In a similar vein, borrowers know that creditors tend to abstain from collection efforts because the latter are costly and often futile. This fact tempts debtors to renege on debt payments. White (1998a) shows that the result is an equilibrium with mixed strategies for creditors (who sometimes collect) and can-pay debtors (who sometimes default).

Finally, in the event of financial difficulty, debtors can abuse the provisions of the law. For example, U.S. law allows debtor to choose between two different bankruptcy procedures (Chapters 7 and 13). Wang \& White (2000) show that this privilege gives debtors incentives to behave strategically prior to filing for bankruptcy. They may shift assets towards exempt property, take advantage of different homestead exemption rates, or simply hide income or wealth (White, 1998b). U.S. law also allows debtors to file for bankruptcy even when their ability to pay is high. Wang \& White (2000) show that requiring debtors to surrender parts of their current assets and of their future earnings reduces incentives for such strategic filing - again at the cost of reduced insurance. ${ }^{23}$

\subsubsection{Ex-post incentives}

Modern bankruptcy regulations combine three different instruments: the seizure of the defaulting borrower's current assets, with more or less generous exemptions; the garnishment of part or all of her future income; and the possible imposition of non-monetary penalties, such as the stigma

\footnotetext{
${ }^{23}$ Though the U.S. bankruptcy filing rate is commonly viewed as high, White (1998a) argues that it surprisingly low. She demonstrates numerically that at least $15 \%$ of all U.S. households would profit from immediately filing for bankruptcy, but instead choose to delay because retaining the option to file in the future is very valuable.
} 
attached to bankruptcy and the reputational effects of default.

When a country's bankruptcy regulations mandate the garnishment of all future income above a preset subsistence exemption amount (as was the case in many European countries until recently), repayment over time may act like a tax on its bankrupt citizens' labor and, hence, cause the latter to adjust their effort levels downward. Abstracting from the issue of debt release, Zaborowski \& Zweifel (1999) provide the first formal analysis of the optimal wage garnishment rate. They show that it should be less than $100 \%$ if incentives are to be preserved. Bigus \& Steiger $(2002,2003)$ analyze the effects of bankruptcy regulations as a whole on economic performance after filing. They propose to make the duration of the repayment period variable. They show that, when the length of that period is contingent on the returns generated by the bankrupt borrower's efforts, the latter has strong incentives to hasten repayments. In other words, mandatory debt discharges are in theory important for preserving human capital following default.

\subsubsection{Trade-offs}

Realizing that a bankruptcy regulation should affect work incentives both before and after the filing, Steiger (2005a, 2005b) provides the first analysis of the performance of various countries' existing bankruptcy regulations in meeting those conflicting goals. She proposes a reform to minimize distortive effects on borrowers' economic performance at both dates. Failed borrowers would surrender current assets plus a fixed sum to be paid out of their future incomes. The fixed sum would vary with borrowers' abilities to pay. This proposal minimizes the gains from strategic filing, while preserving ex-post work incentives by making the debtor the residual claimant ex-post.

The issue of optimizing work incentives before and after bankruptcy is also addressed by White (2005b). As in Wang \& White (2000), a key ex-ante consideration is to provide insurance to honest debtors while discouraging opportunistic debtors from filing for bankruptcy when their ability to pay is high. White (2005b) extends that earlier model to account for post-bankruptcy effort incentives. Her results suggest strong support for the fresh start hypothesis, unless debtors are decisively opportunistic.

Bolton \& Rosenthal (2002) identify a similar tension between ex-ante and ex-post efficiency and welfare considerations, in political votes on debt moratoria. These authors model an agricultural economy in which farmers are cash-constrained and crops are not verifiable. Debt repayments cannot be made conditional on macroeconomic conditions, but agents can vote ex-post on an economy-wide debt cancelation or rescheduling. Such a state-contingent debt moratorium helps 
complete debt contracts and always improves ex-post efficiency. Without a moratorium, defaulting farmers would be forced to give up their farms and work as laborers in order to repay their debts. Economic efficiency would be reduced directly (because such labor is assumed less productive than self-employment) and indirectly (because successful but poor farmers stay under-invested due to liquidity constraints). Welfare would be further reduced as the increased supply of laborers reduces wages. Whether these ex-post debt releases also improve ex-ante efficiency is parameter-dependent. In particular, if the frequency of default-inducing macroeconomic shocks is too high, then credit markets fail in anticipation of too frequent moratoria, which makes everyone worse off. ${ }^{24}$

Though it does not deal with bankruptcy per se, this last paper deals with a closely related issue. Together with the historical and cross-country patterns identified in Section 2, its results help identify two important questions for further work on the trade-off between ex-ante and expost efficiency or welfare considerations in the optimal regulation of bankruptcy. First, should the toughness of bankruptcy laws not only increase with the opportunity for moral hazard (related to diligence, risk taking, or deception), but also decrease with the relative importance of risks that cannot be contracted on? Second, should these laws become more lenient as the scope for labor specialization widens and as the returns to human capital or entrepreneurship increase?

\section{The impact of limited liability rules: Theory and evidence}

Notwithstanding the wishes of the parties to financial contracts (Section 3), most legal systems either impose or prohibit limits on the extent of the borrower's liability upon default (Section 2). What are the consequences for the contracting parties and the rest of society?

\subsection{Qualitative impact}

Financial- and micro-economists have examined the impact of liability rules on contracting parties in a variety of agency settings. Those include situations in which output can only be verified at a cost (Diamond, 1984; Welch, 1995) or is imperfectly observable (Lawarrée \& van Audenrode, 1996); the agent has (Aghion \& Hermalin, 1990; Demougin \& Garvie, 1991) or can choose to acquire (Lewis

\footnotetext{
${ }^{24}$ Cordella \& Levy-Yeyati (2003) use a similar intuition to argue for lender-of-last-resort (LOLR) laws. They observe that, whereas private economic agents cannot make contracts contingent on macroeconomic conditions, governments can credibly precommit to bailing out insolvent banks in economic downturns. They show that the risk-reducing "value effect" brought about by softer LOLR laws outweighs the concomitant increase in moral hazard.
} 
\& Sappington, 1997) better ex-ante information than the principal; the agent makes unobservable choices before (Innes, 1990; Kim, 1997; Robe, 2001) or after (Sappington, 1983) observing the state of nature; and the principal can monitor the agent's actions (Demougin \& Fluet, 2001). ${ }^{25}$

Most of those papers seek to characterize the impact of limited liability rules analytically, in partial-equilibrium settings, under conditions (such as a single-period horizon or risk-neutrality) that preserve mathematical tractability. Overall, they conclude that liability limits have a firstorder qualitative impact on the terms of the contract.

Whether this impact is good or bad for the contracting parties depends on the environment in which they operate. With ex-ante asymmetric information, a legal ban on strong penalties can be welfare-enhancing if they act as inefficient signals. By contrast, with moral hazard, the world is often one of symmetric ex-ante information in which borrowers and lenders both benefit when they know that the courts will enforce harsh penalties (Rea, 1984; Aghion \& Hermalin, 1990). ${ }^{26}$

In general equilibrium settings, the main papers that characterize analytically the impact of default and limited liability rules are Dubey et al. (1990, 2005), Zame (1993), and Araujo \& Pascoa (2002). ${ }^{27}$ Dubey et al. (2005) and Zame (1993) model default penalties entirely in terms of utility punishment. They show that exogenous restrictions on the harshness of these penalties can lead to the breakdown of credit markets. Araujo \& Pascoa (2002) abstract from such utility penalties. Instead, they explore the effects of bankruptcy rules that are arguably more in line with current bankruptcy laws and with the decreasing importance of the moral stigma attached to default. Precisely, they consider a proportional reimbursement rule (in which creditors are paid back in proportion to the amount of credit extended) as well as a non-proportional rule in the sense of Aumann \& Maschler (1985). In both cases, they show that a credit markets clear.

\footnotetext{
${ }^{25}$ See Sappington (1991) and Demougin \& Fluet (2001) for more detailed reviews of that literature.

${ }^{26} \mathrm{~A}$ similar conclusion is reached in the efficiency-wages literature, which shows how involuntary unemployment problems might be alleviated if workers could post bonds or face potentially severe penalties, such as forfeiting lifetime retirement benefits - see, e.g., Carmichael (1989) and references therein. Another strand of research building on a similar intuition is found in the development economics literature. It explains the wide use of share tenancy contracts (rather than fixed rents) by invoking limited liability in the presence of moral hazard from effort (Shetty, 1988; Laffont \& Matoussi, 1995; Ray \& Singh, 2001), risk-shifting (Basu, 1992; Sengupta, 1997), or both (Ghatak \& Pandey, 2000). Laffont \& Matoussi (1995) and Pandey (2004) marshall empirical evidence from Tunisia and India to support these theoretical models. Finally, Basu, Bell, \& Bose (2000) show that whether limited liability constraints are binding or not affects the optimality of interlinking credit and labor markets in rural settings.

${ }^{27}$ Zame (1993) and Kocherlakota (1996) analyze the role of default in, respectively, helping to complete financial markets or in contributing to market incompleteness in the first place. See Athreya (2005) for a good discussion.
} 


\subsection{Quantitative impact}

Once liability laws and bankruptcy regulations are known to affect significantly the terms of the contract and the credit market equilibrium, the next issue is the size of the resulting deadweight losses or, instead, welfare gains. Computational advances have made answers possible.

Athreya (2002) analyzes the optimal severity of bankruptcy laws, when governments must trade off the consumption-smoothing benefit of lax penalties for default against variable administrative and non-monetary deadweight costs associated with bankruptcy filings. By assumption, borrower characteristics are not observable. Hence, loans can be priced in line with average (not individual) repayment rates. In such an environment, abolishing debt releases altogether would increase welfare relative to both the previous and the 2005 U.S. bankruptcy regulations. The analysis, however, abstracts from shocks as a reason for bankruptcy and posits that default is always strategic though exogenous shocks account for at least $20 \%$ of all U.S. bankruptcies (Athreya, 2005).

Chatterjee, Corbae, Nakajima, \& Rios-Rull (2005a) introduce uninsured shocks to borrower income, marital status, and wealth. Individuals can smooth consumption by trading a single riskfree asset and by defaulting on unsecured loans. Default limits future access to the credit market, so reputation matters. Finally, creditors can observe some individual debtor characteristics (e.g., the terms of a loan can be tailored to the borrower's wealth). Chatterjee et al. (2005a) establish the existence of a recursive credit market equilibrium, characterize default behavior, and derive the endogenous borrowing limits in such an environment. They also calibrate the model to U.S. data and institutional features. Based on their numerical results, they argue that introducing "means testing" would significantly increase the amount of credit extended and overall welfare. ${ }^{28}$

Finally, Sartre \& Li (2006) analyze the general-equilibrium implications of U.S. "bankruptcy Chapter" choice in a production (rather than endowment) economy. In their model, individuals can smooth consumption not only by saving in a risk-free asset or defaulting on unsecured loans, but also by changing their work-leisure decisions. In contrast to endowment-economy studies, they find that eliminating bankruptcy lowers welfare and that debt release is highly desirable.

\subsection{Impact of limited liability rules: Empirical evidence}

The above theoretical and numerical results are derived in stylized settings. They show that the optimal liability rules and bankruptcy laws vary widely with the model environment - e.g., the

\footnotetext{
${ }^{28}$ Chatterjee, Corbae, \& Rios-Rull (2005b) further analyze reputation acquisition in credit markets.
} 
main type of agency conflict (moral hazard vs. adverse selection) or the nature of the economy (production vs. endowment). Regardless of these differences, they suggest that liability rules can strongly affect both the terms of financial contracts and the welfare of contracting parties. These conclusions are broadly supported by a small but growing body of empirical evidence.

\subsubsection{Anecdotal evidence}

An early documented example of the impact that limited liability rules can have is provided by the regular collapse of ancient Israel's credit markets in anticipation of the seventh or Sabbatical year (Wylen, 1996). The septennial release of debts owed by poor Jews was particularly detrimental to the debtors until a remedy was found by Hillel the Elder, who led the Pharisees between 50-10 BCE. He invented the legal fiction of the prozbul, a promissory note which transferred the debt from the private lender to the court for the period of the Sabbatical year. Since the Sabbatical year canceled only private but not public debts, the outstanding debts remained in force and were returned to the original lender by the end of the Sabbatical year.

Another historical example is provided by the contrast, during the Middle Ages, between the respective abilities of municipal and territorial governments to borrow large sums of money (Kohn, 1999a). In towns, all free men were jointly responsible for the city's debts: their persons and property could be held for ransom in case of default. Hence, the risk of default was small and the market in municipal debt flourished. In contrast, autocratic or territorial rulers faced serious difficulties when issuing annuities, because the latter were the local prince's debt and, consequently, lenders had no recourse in case of default.

More generally, the structuring of sovereign loans over the ages illustrate the negative consequences for an individual borrower of having de facto or de jure limited liability. This is because sovereigns can be viewed in effect as living entities and, thus, be analyzed like individuals. Outhwaite (1968) documents how, in order to borrow money in Antwerp, the English Crown in Elizabethan times had to cajole London merchants into guaranteeing the Crown's loans. Conklin (1998) provides a formal analysis of how a Genoese-led lending cartel found a different solution to the risk of default by Elizabeth I's nemesis, Philip II of Spain. Cartel members managed to create a penalty for default by linking their loans to the delivery of specie from Spain to the Low Countries, on which they had a monopoly. When Philip II tried to renege during his war with the Dutch, the cartel applied the penalty (thereby preventing payments to Spanish troops) and the king relented. Conklin (1998) argues that estimates of the Spanish Crown's cost of enduring the penalty and its 
ability to repay, as well as the debt ceiling imposed by the cartel, are consistent with the predictions of a sovereign-lending model developed by Bulow \& Rogoff (1989).

\subsubsection{The mitigating role of reputation}

What if lenders operate in an environment in which similar penalties cannot be constructed? The evidence suggests that lenders are not completely helpless in that case, because the creation and upkeep of a reputation can act as a powerful incentive for borrowers not to misbehave. English (1996) analyzes defaults by U.S. states in the 1840 's. He shows that, although creditors could practically do little to enforce payment, most states eventually did repay in full in order to maintain access to capital markets. Based on evidence from cotton-bonds issuance and service by the Southern Confederacy from 1861 to 1865 , Weidenmier (2005) also concludes that reputation or another type of sanction is necessary to support high levels of lending in international capital markets. ${ }^{29}$

At the individual level, the stigma associated with filing for personal bankruptcy is one of these other possible sanctions. Fay et al. (2002) establish empirically that, in the United States, this stigma does lessen the impact of debtor-friendly bankruptcy laws on households' incentives to file in the first place. They also find that U.S. households tend to increase strategic behavior as the financial benefit from bankruptcy rises and conclude, as do Gross \& Souleles (2002), that the stigma for default has fallen amidst an ample increase in bankruptcy filing rates. With a more recent data set, Livshits, McGee, \& Tertilt (2005) find similar results. Here the increase in filing rates is attributed to the decrease in stigma and the transactions costs of lending.

Overall, these studies suggest that stigma alone is insufficient to deter moral hazard in U.S. consumer credit markets. In this environment, past behavior should matter in obtaining credit. U.S. credit files include a "flag" for ten years after a bankruptcy. Musto (2004) finds that failed borrowers have a higher probability of repeated default. He also documents that, though bankrupts are not excluded from credit altogether, these flags hurt borrowers' ability to obtain credit. ${ }^{30}$

\footnotetext{
${ }^{29}$ Evidence that reputational concerns are a key disciplining device in other agency relationships than in purely financial ones is given by Brandt \& Hosios (1996) in the case of employment contracts with a credit component, using data from a household-level survey taken in 1935 rural China.

${ }^{30}$ The role of personal credit registries is also addressed in an experimental study by Brown \& Zehnder (2005). They find that the existence of these credit registries increases the likelihood of repayment as well as the volume willing to extend by lenders, at least when long-term relationships with one lender are not possible.
} 


\subsubsection{Impact of limited liability rules on society}

In our discussion thus far, we have concentrated on the implications of limited liability rules for the contracting parties. Often, though, legislators restrict the freedom of contracting parties to choose their own liability regime because that very freedom (or the lack thereof) has consequences both for them and for society as a whole.

Of course, to the extent that economic agents can circumvent bankruptcy regulations, the relevant macroeconomic variables should be unaffected. Agarwal, Liu, \& Mielnicki (2003), for example, document that borrowers switch between formal and informal bankruptcy depending on the generosity of their home state's garnishment and property exemption rules. In a similar vein, Han \& Li (2004) do not find support for the argument that debtor-friendly laws help preserve human capital by maintaining work incentives. They document that filing for bankruptcy has no discernable positive impact on annual hours worked by bankrupt U.S. households, a result attributed mainly to the wealth effects of debt discharge.

Empirical cases that limited liability rules have strong significant macroeconomic implications are made by Gropp et al. (1997), Berkowitz \& Hynes (1999), Lin \& White (2001), and Berkowitz \& White (2004). Those authors measure the effects of debtor-friendly bankruptcy laws in the markets for, respectively, personal credit, mortgages, home improvement loans and mortgages, and smallbusiness loans. They use variations in personal bankruptcy laws across U.S. states to tease out the impact of these laws on those credit markets and on lender and borrower behavior. ${ }^{31} 32$

Gropp et al. (1997) document that the U.S. states allowing individuals to retain more assets when they file for bankruptcy see a net shift of non-business credit from low-asset households to high-asset ones. These authors also show that the demand for credit is higher, and the supply of credit is lower, in states with high personal bankruptcy exemptions rates. Using a recent survey

\footnotetext{
${ }^{31}$ Kowalewski (2000) discusses the early quantitative research on personal bankruptcy and the related data.

${ }^{32}$ Variations in exemption rates across U.S. states have also been used to study the motives behind more or less generous personal bankruptcy laws. Historically, states such as Texas adopted debtor-friendly laws to attract settlers from other states (Goodman, 1993). The strength of the current incentives to move across state lines prior to filing is subject to debate (Brinig \& Buckley, 1996; Elul \& Subramanian, 2002). Nowadays, generous personal bankruptcy laws may reflect insurance motives. To wit, Hynes et al. (2004) find that states with few welfare benefits are more likely to have high exemption rates. Filer \& Fisher (2005) similarly find that Chapter 7 bankruptcy has a positive effect on debtors' food consumption. Consistent results are found by Lehnert \& Maki (2005). They find a U-shaped relationship between consumption insurance and bankruptcy exemptions, i.e., higher borrowing and filing rates in states with more generous exemption rates.
} 
of small business finance in the U.S., Berkowitz \& White (2004) show that both the probability of unincorporated businesses' getting credit and the size of the loans obtained decrease with the debtorfriendliness of U.S. states' personal bankruptcy laws. Those results are in line with predictions that credit rationing will increase in jurisdictions that allow individuals to retain more assets when they file for bankruptcy (Longhofer, 1997). They are also consistent with empirical evidence that, because mortgage lenders can foreclose regardless of the personal property exemption in bankruptcy proceedings, high exemption levels do not increase mortgage rates or increase the probability of being denied a mortgage (Berkowitz \& Hynes, 1999). ${ }^{33}$

\section{The law and investors in defaulting businesses}

In light of the severe legal penalties imposed even on non-fraudulent debtors (Section 2), entrepreneurs and other investors have long tried to limit their liability resulting from commercial transactions. When a business is not incorporated, its liabilities become those of its owners. In that sense, a country's personal bankruptcy regime also establishes the effective bounds on investors' liability, should their unincorporated business default (Berkowitz \& White, 2004). When a firm has been incorporated, however, one must differentiate between corporate and individual liability. In particular, incorporation raises two questions. First, can any investor enjoy limited liability, i.e., can investors' liability in case of default be restricted to their investment? Second, if not, does there exist some bound (other than that implied by the personal bankruptcy regime) on investors' liability - such as a finite multiple of their original investment?

The push by entrepreneurs and investors to circumscribe their potential liability is not new. Jewish rules derived from the Torah, for instance, stipulated that commercial debtors could neither be imprisoned nor be subjected to involuntary servitude (Resnicoff, 1998). In ancient Greece and Rome, in the Byzantine Empire, and in medieval times, default was dealt with harshly. As a result, trade around the Mediterranean was financed with sea loans that did insure the borrowing merchant, at least against losses due to events beyond his control. These sea loans have survived, virtually unchanged through the ages, as the modern bottomry loans (Hoover, 1925).

Since early on, Islamic merchants have used a particular profit-sharing agreement, the mudaraba, to limit their liability in a business enterprize to the amount of their original investment (Cizakca, 1996). In contrast, partners in twelfth-century Italian ventures were jointly and severally liable

\footnotetext{
${ }^{33}$ In contrast to Berkowitz \& Hynes (1999), Lin \& White (2001) include data on home improvement loans and find a significant negative relation between exemption rates and the probability of being turned down for a mortgage.
} 
for all of their projects' debts (Carney, 1999). The first merchant banks in medieval Italian city republics also operated under unlimited liability: they were partnerships, with all the partners jointly and severally liable for the bank's debts (Kohn, 1999b). Given the high risk of incurring losses much in excess of their original stake, however, Italian investors shortly adopted the mudaraba from their Arab counterparts (Cizakca, 1996). In practice, the new business form - now renamed commenda - maintained an unlimited liability regime only for the tractator (the agent or active partner) but limited the liability of the stan or commendator (principal or arms-length investor) to the amount the latter had invested. Legal recognition more or less rapidly followed commercial practice. When Florence legally acknowledged the accomandita in 1408, limited liability finally became the law there for sleeping partners (Kohn, 1999a). Called Wedderlegginge in Hanseatic cities such as Lübeck (Schiller \& Lübben, 1880), and commandite in France where it was legalized in 1673 (Boileau, 1945), the business form soon spread across much of Continental Europe. ${ }^{34}$ An exception is England, where the commenda never became popular (Cizakca, 1996; Carney, 1999).

Once associations with limited investor liability had become accepted, the next logical step was to devise joint-stock companies with limited liability. The idea was to make possible long-lived corporations with separate management and ownership, whose investors could exchange shares easily. Prototypes of this new company type, the carati, can again be found in Italian city-states. Cizakca (1996) argues that Genoa was at the forefront of this innovation; indeed, Boileau (1945) documents that a Genoese bank, functioning along these principles and founded in 1407, lasted more than three centuries. English joint-stock companies, Dutch voorcompagnieën (predecessors of the 1602 Verenigde Oost-Indische Compagnie) and French sociétés anonymes (such as the Compagnie des Indes Orientales and Compagnie des Indes Occidentales) followed in the next few centuries. In Russia, the first joint-stock company was founded in 1799 .

In the nineteenth century, businesses started being allowed to form freely on a joint-stock basis. Until then, in many European states, investors who wished to form joint-stock companies could not do so unless they were first granted a request by the appropriate authorities. In Great Britain and Ireland, for example, the joint stock company with tradable shares was not made generally available for banks until the mid-1820's and for all businesses until 1844 (Patterson \& Reiffen, 1990; Hickson \& Turner, 2003; Hansmann \& Kraakman, 2003).

Even when these English joint-stock companies enjoyed success, though, they rarely had limited

\footnotetext{
${ }^{34}$ Precisely, the French ordinance of 1673 recognized two types of commandites. The first was meant for associations between négociants or businessmen. The second, between merchants and non-merchants, allowed the latter to legally limit liability to their investment upon registration of the venture. See Boileau (1945) for a discussion.
} 
liability for equity-holders until close to the twentieth century (Smart, 1996). ${ }^{35}$ Only late in the nineteenth century did legislators start granting investors the freedom to constitute limited-liability companies without prior case-specific official approval. Canada did so in 1850 (Weinstein, 2003). The United Kingdom did so via the 1855 Limited Liability Act and the 1856 Joint-Stock Companies Act Smart (1996). Russia followed suit in 1857; France, in 1867; Belgium, in 1870. ${ }^{36}$ Likewise, the common law rule in most U.S. states in the second part of the nineteenth century was that a corporation's shareholders were not liable for its debts (Livermore, 1935; Macey \& Miller, 1992).

Had limited shareholder liability for corporate debts become the norm by the turn of the twentieth century, in most countries and industries? No. Shareholders of U.S. banks, in particular, long remained liable beyond their initial investment. From early in the nineteenth century, individual U.S. states imposed departures from the common law's limited liability principle, ranging from pro-rata several liability to unlimited liability for bank shareholders. The National Banking Act of 1863 imposed double liability for shareholders of national banks. It was only repealed in 1933 for new banks, and some older banks kept operating under double liability until 1953 (Macey \& Miller, 1992). ${ }^{37}$ Following the thrift crisis of the 1980's, the U.S. Federal Reserve Board attempted to restore contingent liability for some bank stockholders in an attempt to alleviate concerns about the risk-taking incentives created by limited liability (Schinski \& Mullineaux, 1995).

Recent cases of unlimited liability can also be found outside the banking sector. By law, shareholders of all Californian non-bank corporations bore pro-rata unlimited liability until 1931 (Weinstein, 2005). American Express, a large U.S. joint stock company with numerous shareholders, operated under unlimited liability until 1965 (Grossman, 1995). In most European countries, many companies are incorporated as commandites - whose active shareholders bear unlimited liability for corporate debts. Examples include such mammoth firms as Michelin in France and Henkel in Germany. Further, many investors in smaller entreprises still choose to form unlimited liability businesses today. Examples include sociétés en commandite simple (SCS) in France and Belgium, where they are all the more common there that they were de jure the default corporate form until

\footnotetext{
${ }^{35}$ The unlimited liability standard was reaffirmed by the 1720 Bubble Act (repealed in 1825) De facto, though, it could be contracted around except in cases of fraud (Maitland, 1904; Franks \& Sussman, 2005). An exception was sea trade: in that sector, for idiosyncratic reasons, limited de jure liability was typical (Cizakca, 1996).

${ }^{36}$ The French had preceded the British, granting the freedom to constitute sociétés anonymes in 1791, but this attempt proved ephemeral: the right was revoked in 1793, granted again in 1795, but taken back once more in 1807.

${ }^{37}$ Scotland provided another famous example of unlimited liability for bank owners during most of the nineteenth century. Unlimited liability was the de facto rule there for the shareholders of all but three banks until 1879, and many banks retained multiple reserve liability thereafter (Carr \& Matthewson, 1988; Evans \& Quigley, 1995).
} 
1996. In the United States, the origin of unlimited liability partnerships can be traced back to the French SCS (Kessler, 2003). They were popular with U.S. accounting firms until a spate of massive lawsuits following the 1980's thrift debacle, and remain ubiquitous in law or medicine. In the United Kingdom, the Lloyd's of London syndicates are still unlimited-liability partnerships, despite massive losses sustained by the "names" early in the last decade and the recruitment (since 1994) of corporate members with limited liability.

The idea one might draw from the preceding discussion is that individual investors today are essentially free to choose or decline limited liability for the corporations they form. There are three caveats to such a sweeping conclusion. First, even if investors have formally incorporated into a limited liability corporation, banks may refuse to lend unless investors provide personal guarantees for corporate loans. Second, there have been many instances of investors' being denied their liability shield. The circumstances in which the "corporate veil" can be lifted vary from country to country. In some European countries, it is sufficient that the failing firm be found undercapitalized. In the United States, one also finds instances of courts removing limited liability protection, though liability extension cases there are rarer. They almost invariably involve closely held corporations whose shareholders actively participated in the business - individuals in small corporations, or corporate parents in large ones (Easterbrook \& Fishel, 1985; Carney, 2001). ${ }^{38}$ Third, there is a renewed debate on whether limited liability ought to be scrapped for all investors (not just shareholders) in some instances, such as debts resulting from mass corporate tort (Hansmann \& Kraakman, 1991; Pitchford, 1995; Karpoff, Lott, \& Rankine, 1998; Dionne \& Spaeter, 2003).

We thus seem to have come full circle regarding liability for either personal or corporate debts. While it might seem that jurisdictions have been converging worldwide toward a universal rule of limited shareholder responsibility for corporate liabilities (Hansmann \& Kraakman, 2003), the dispute remains as lively as ever between proponents of debtor-friendly laws and opponents who contend that investors ought not to be able to walk away easily from their obligations. We now turn to discussions of why businesses may prefer a given liability regime (Section 6) and the impact of government constraints on their choices (Section 7).

\footnotetext{
${ }^{38}$ U.S. courts also often consider possible under-capitalization of the firm when deciding whether to lift the corporate veil (Easterbrook \& Fishel, 1985); in some jurisdictions, under-capitalization alone suffices to lift it (Carney, 1999).
} 


\section{Optimal choice of shareholder-liability regime}

The determinants of liability-structure choice differ, depending on whether lenders' interests conflict with those of one or more groups of equity investors. This section is organized accordingly.

\subsection{Simple conflict structures}

The long history of unlimited liability, outlined in Section 2.1, suggests that severe penalties can help provide ideal incentives in certain financial agency relationships. Indeed, Section 3.1 discusses various settings in which entrepreneurs voluntarily operate under unlimited liability or precommit to harsh penalties in case of default. These settings include environments in which lenders cannot verify cash-flows (Townsend, 1979; Diamond, 1984; Lacker, 2001), borrower actions (Mirrlees, 1976; Robe, 2001), or project- or borrower-quality (Rea, 1984; Aghion \& Hermalin, 1990).

Still, the fact that limited-liability ventures and companies already existed more than a thousand years ago suggests that, in at least some environments, contracting parties may be strictly better off when they agree to operate under limited liability and with an upper bound on penalties. This is because, in practice, unlimited liability can entail costs beside advantages for those parties.

In some cases, the costs arise from the very nature of financial contracting. Evans \& Quigley (1995) model banks' choice of liability regime, in a framework where shareholders have superior information about the financial position of their bank. They show that, if the information can be provided sufficiently cheaply to creditors under limited liability, then that regime is optimal because it allows shareholders to shed some of the monitoring and risk-bearing costs onto creditors. Conversely, if bank depositors can monitor shareholder wealth at lower cost than bank assets, and if they are willing to compensate shareholders for bearing all the costs of overseeing management and facing all the bank's business risk, then unlimited liability may prevail. These authors suggest that innovations in the provision of information late in the nineteenth century helped spur the move away from unlimited liability banking in Scotland.

In other cases, the advantages or the costs of unlimited liability result from government policies. Horvath \& Woywode (2005), for example, develop a costly-state-verification model in which entrepreneurs choose the liability status under which they operate. They must trade off the posited tax and cost-of-capital advantages of an unlimited-liability business form, against the higher risk

of catastrophic losses that such a form involves. Numerical simulations and empirical tests of the model suggest that risk aversion is the more important consideration for German start-ups. 


\subsection{Corporations}

In the models of Section 6.1, the sole conflict is between an entrepreneur and a financier, or between shareholders and creditors. There is no difference of opinion or interests between entrepreneurs and shareholders, or between different shareholders. In particular, investors' desire to trade their shares is, by construction, not pertinent to the choice of limited liability.

Yet, creating conditions propitious to share trading and to the development of a broad shareholder base is often identified as a key reason why firms have historically attempted to operate under limited liability. To see why, notice that, under unlimited liability, a firm's value to its creditors and stockholders depends on the latter's net worth. That is, creditors' right to seize shareholders' personal assets is only as valuable as the assets to be seized. Creditors also indirectly benefit from shareholders with large personal assets, because such shareholders have stronger incentives to monitor managers closely and to refrain from engaging in moral hazard themselves. Analogously, the price that an investor should pay for an unlimited liability company's shares is inversely related with the size of that investor's personal assets (Halpern, Turnbull, \& Trebilcock, 1980) and, in the case of jointly and severally unlimited liability or multiple pro-rata liability, positively related with the value of other shareholders' assets (Woodward, 1985). Consequently, allowing trading in the shares of unlimited liability corporations simultaneously raises several problems. Debtholders and shareholders will both need to monitor shareholders' wealth, a very costly task when shares are widely held (Jensen \& Meckling, 1976). Creditors will fear that new shareholders may be less creditworthy than those they are replacing and be more likely to engage in moral hazard. ${ }^{39}$ For shareholders, the net welfare effect will depend on whether they are divesting or not. Non-trading shareholders are harmed by the arrival of relatively less wealthy investors. Conversely, by selling their stake to less wealthy investors, shareholders can walk away from the consequences of their own actions and avoid the impact of negative shocks beyond their control, such as economic recessions. ${ }^{40}$

\footnotetext{
${ }^{39}$ Kane \& Wilson (1998) provide empirical support for these fears. They document that the broadening stockholder base of large banks during the stock-market bubble of the late 1920s undermined the efficiency of double liability provisions in controlling incentive conflict among large-bank stakeholders.

${ }^{40}$ The law may be written, or the courts may interpret the law, to alleviate those concerns. For example, in order to protect creditors' interests under the 1863 National Banking Act, U.S. courts routinely upheld assessment liability in cases of opportunistic share transfers carried out to avoid liability, including during the Great Depression (Macey \& Miller, 1992). Likewise, when the City of Glasgow Bank (an unlimited-liability Scottish bank) failed in 1878, liability was made to continue for one year after a share sale, significantly increasing the number of persons liable for calls see Evans \& Quigley (1995) and references therein. See also Tung (1999) for a discussion of successor liability.
} 
Winton (1993) models firms' choice of liability regime in such an environment, where ownership and management are separate and shareholders must monitor managers. Free-riding is a problem, because individual monitoring efforts are not observable. If shareholders' assets can be costlessly observed but can only be liquidated at a cost, then unlimited liability is optimal as it reduces freeriding (default penalties are higher) and minimizes expected costs (liquidation is contingent upon default). If shareholders' assets are not freely observable, however, then contingent liability is not viable - unless restrictions are placed on share trading or shareholders expend effort to verify one another's assets. ${ }^{41}$ In that case, contingent unlimited liability may (but need not) remain optimal, as shareholders must balance the improved incentives to monitor managers against the reduced liquidity of their shares and the cost of personal-asset verification. ${ }^{42}$

\subsection{Ex-post incentives}

The institution of limited liability allows the disassociation of the business itself from its current management in the event of distress. Equally, it enables entrepreneurs and other equity holders to protect their personal assets from the grasp of the business' creditors. One might therefore argue that there is little point in discussing ex-post effects on investors beyond Sections 6.1 and 6.2, which focus on how large investors' losses can be over and above their stakes in the firm.

Yet, just like individual borrowers may be allowed to retain some of their assets in the event of personal bankruptcy (Section 3), failing firms are often allowed to reorganize. They can do so as the result of a legal mandate, such as in the U.S. Chapter 11. But many firms are directly allowed to reorganize by their creditors in private workouts, when these creditors find it to their advantage. In some cases, creditors agree because the alternative is even worse - for example, if equity holders facing total loss decide to "go for broke," to exploit the option value of delaying liquidation or, more generally, if they can credibly threaten to destroy some of the firm's value (Povel, 1999; Hart, 2000). But there may also be some genuine potential gains from reorganization, for example when a firm's assets are worth more in combination with the entrepreneur or current management than without them (Hart \& Moore, 1994) or when leniency by creditors helps elicit information from the entrepreneur (Kalay \& Zender, 1997; Povel, 1999). In other words, creditors may find it optimal

\footnotetext{
${ }^{41}$ For example, using the archives of a nineteenth-century Irish unlimited liability joint-stock bank, Hickson \& Turner (2003) conclude that the governing bodies of these banks, constrained by special legal restrictions on share trading, managed to prevent shares transfers to the less wealthy.

${ }^{42}$ See also Easterbrook \& Fishel (1985), Carr \& Matthewson (1988), and Grossman (1995).
} 
to allow equity investors to retain some of their investment. ${ }^{43}$

The anticipation of such ex-post deviations from the Absolute Priority Rule (APR) can in turn exert a strong influence on the ex-ante and interim decisions of managers. These deviations may improve incentives for managerial effort and investment in firm-specific human capital, and reduce incentives for managerial entrenchment (Bebchuk \& Picker, 1993). However, they may also make strategic default more appealing (Hart \& Moore, 1998; Longhofer, 1997), and affect risk taking and project choice (Eberhart \& Senbet, 1993; Bebchuk, 2002). Bebchuk (2002), in particular, identifies a risk-taking trade-off. Because anticipated deviations from APR increase the payoffs of shareholders in bad states of the world, they provide incentives for them to take on riskier projects than would be optimal in a first-best environment in which firm (rather than equity) value is maximized. For the same reason, equity holders' appetite for risk taking decreases after bankruptcy.

\section{The impact of limited liability rules}

In the absence of exogenous constraints, the parties to financial contracts may optimally prefer more or less severe penalty regimes, depending on the conditions they face (Section 5). Yet, most legal systems either impose or prohibit limits on the extent of economic agents' potential liability (Sections $2 \& 3$ ). What are the consequences for the parties and the rest of society?

\subsection{Theoretical analyses}

Exogenous liability limits can intensify conflicts between arms-length investors and corporate insiders (entrepreneurs or "active" shareholders). In particular, when the latter's actions are difficult to monitor, limited liability reinforces insiders' risk-shifting incentives (Jensen \& Meckling, 1976) and discourages their diligence (Innes, 1990).

To the extent that they reinforce these underlying agency conflicts, limited liability mandates should bring about significant changes in the governance mechanisms meant to control insiders. For example, Green (1984) shows that companies seeking outside finance can tailor the types of securities they issue in order to commit against opportunistic behavior. Specifically, risk-shifting can be deterred by giving warrants to bondholders.

\footnotetext{
${ }^{43} \mathrm{~A}$ detailed analysis of corporate bankruptcy and private reorganizations is beyond the scope of our paper. See White (2005a) and Schwartz (2005) for discussions of the relevant law and economics literature. See White (1996) and Armstrong \& Riddick (2003) for comparisons of national corporate bankruptcy laws in different countries.
} 
A natural question is how the time horizon of the agency relationship affects the impact of liability rules. The answer depends on the nature of the agency problem - in particular, whether the agent must take a series of decisions.

On the one hand, if borrowers can be forced into bankruptcy as soon as their current wealth becomes negative, then the effort disincentives created by limited liability in a static environment are mitigated when projects generate cash-flows for several periods (Suen, 1995). Intuitively, if all projects have positive net present value, then the one-shot gain from shirking is partly balanced by a long-term loss due to the higher probability of giving up positive future cash-flows in the event of bankruptcy. When moral hazard takes the form of risk-shifting rather than shirking, the agency problem can even be fully eliminated if the expected cost of bankruptcy in terms of foregone future profit opportunities more than outweighs the short-term gain.

Diamond (1989) obtains a similar result when neither borrowers' choices of short-term projects nor those projects' outcomes are verifiable, and the sole threat available to lenders is to liquidate a business upon default. Because borrowers' are long-lived and their default history is public knowledge, the prospect of capturing future rents from a good reputation lessens their incentives to take on excessively risky projects in the early stages of their borrowing career.

On the other hand, Palomino \& Pratt (1999) use a portfolio-management setting to show that, when risk-shifting problems compound shirking issues and the agent can adjust his risk profile each period, the first-best may be achieved in one-shot relationships but not in multi-period ones. Intuitively, with a single period, introducing a discontinuity in the risk-neutral agent's payoff function (such as promising bonuses to a portfolio manager) suffices to overcome the effects of limited liability. With more than one period, however, the agent can use later risk-shifting opportunities to offset the impact of early decisions, so that only a contract linear in the final-period outcome could implement the first best - but linear contracts are incompatible with limited liability.

\subsection{Empirical analyses}

Though there exist few numerical studies of financial agency problems in entrepreneurial or corporate settings (Fluck, Garrison, \& Myers, 2005), a growing number of empirical studies shows that liability rules do affect both the terms of financial contracts and the welfare of contracting parties.

Many businesses are unincorporated, so entrepreneurs are often personally liable. Consistent with this fact and the insurance role of bankruptcy, Fan \& White (2003) find that higher exemption rates promote entrepreneurial activity. Berkowitz \& White (2004) likewise document that more 
generous exemptions increase the probability of small-business owners to be turned down for credit, and are associated with smaller loans and higher interest rates.

For large corporations, nineteenth- and early-twentieth-century banks afford some of the richest opportunities to study liability rules' impact. In the United States, Esty (1998) observes that, between 1863 and 1933, state and federal banking laws subjected the owners of different banks to a variety of liability rules for the obligations of their banks. One could therefore, during that period, find banks operating in the same market but under different liability regimes, ranging from limited to multiple pro-rata and even unlimited liability. Consistent with the intuition that increasing bank shareholders' maximum liability should lessen their incentives for risk taking, Esty (1998) shows empirically that risk taking by banks was indeed significantly negatively related to the severity of the liability rule - mainly due to less risky asset holdings and greater net worth. Using bank balance sheet and failure data, Grossman (2001) reaches the same conclusion. ${ }^{44}$

\subsection{Societal implications}

In our discussion thus far, we have concentrated on the implications of limited liability rules for the contracting parties. Often, however, legislators restrict the freedom of contracting parties to choose their own liability regime because that very freedom (or the lack thereof) has consequences both for them and for society as a whole.

On the positive side, bankruptcy laws provide a means for the contracting parties to credibly commit to a path of action in the event of default. As a result, coordination problems may be alleviated and corporate investment inefficiencies may be reduced (Gertner \& Scharfstein, 1991), and entrepreneurs or managers may agree to invest more in firm-specific human capital (Berkovitch, Israel, \& Zender, 1997, 1998). The protection afforded by bankruptcy regulations is also socially beneficial, if corporate bankruptcy laws can be designed to induce managers to continue operating in situations in which it is socially efficient to do so but it is not individually rational for investors to provide these managers with the requisite incentive structure (Wohlschlegel, 2003). Likewise, absent a mandatory "fresh start" policy, entrepreneurs would generally emerge from bankruptcy with a larger debt burden than is socially efficient (Ayotte, 2007).

On the downside, in some economic sectors, merely allowing agents to opt for limited liability could create so serious an externality that it would be optimal for the government to ban the possi-

\footnotetext{
${ }^{44}$ Macey \& Miller (1992) provide evidence suggesting that a bank's capital-to-assets ratio is inversely related to the severity of the liability regime for its owners. They do not, however, test the statistical significance of that relation.
} 
bility altogether. Take the implications of bank managers' risk-taking behavior for the stability of a country's financial system. Given that liability laws influence risk-taking (Esty, 1998; Grossman, 2001), one can hardly dissociate moral hazard issues in banks from the extent of their stockholders' (and managers') maximum liability in case of default. In a similar way, deposit insurance programs, by guaranteeing deposits in the event of insolvency, reduce depositors' incentives to monitor bank managers closely, which encourages the latter to take risk and, thus, may indirectly weaken the banking system - see, e.g., Thakor (1996).

Unlimited liability may also prevent shareholders from reaping the full benefits of portfolio diversification (Manne, 1967). This is because, with unlimited liability, investing in many different companies increases one's risk of facing massive losses. Since rich investors care more about such risk, they are likely to concentrate their shareholdings into a few firms that they can monitor closely. ${ }^{45}$ A case is therefore often made that firms ought to be allowed to operate under limited liability lest unlimited liability slow the development of capital market.

Whether or not this last argument matters in practice is an issue that remains to be settled. A case study by Grossman (1995) finds little evidence that the characteristics of American Express stockholders in the 1950's were markedly different from those of shareholders in limited-liability corporations, or that the market for Amex shares was negatively affected by unlimited liability. The study also argues that Amex's shares did not command any particular risk premium despite the company's exposure to potentially devastating claims. In contrast, Evans \& Quigley (1995) document that shares of unlimited liability Scottish banks in the nineteenth century carried a risk premium over the shares of their limited liability counterparts, and that this premium went up greatly following the failure of an unlimited liability bank in 1878. Because these authors explicitly abstract from the possibility that banks' portfolio riskiness could depend on the liability regime, the large risk premium they measure could even be an underestimate (Esty, 1998).

Finally, state-mandated liability rules appear to have other, perhaps less obvious, economy-wide costs. For example, they may affect the intensity (or even the existence) of competition in the product market and, hence, consumer welfare. Take a market dominated by a monopolist, who has deep pockets and is willing to wage merciless price wars to defend itself against entry. One might believe that all potential competitors would be deterred from entering such a market, since they should face certain ruin if they did. Fulghieri \& Nagarajan (1996), however, show that limited liability rules can discourage predatory behavior by the monopolist. Intuitively, if the entrant takes

\footnotetext{
${ }^{45}$ Similarly, a case is made by Wiggins \& Ringleb (1992) that, even without monitoring problems, increased risk under unlimited liability makes it worthwhile for firms to compartmentalize their activities and not diversify.
} 
on large amounts of debt and enjoys limited liability protection in case of bankruptcy, then he has little to lose from a price war and can therefore credibly afford what would otherwise be a reckless strategy, i.e., enter the market. ${ }^{46}$ A corollary to this argument is that prohibiting potential entrants from using limited-liability debt financing is akin to eliminating the threat of entry and, thus, to allowing for monopolistic price levels in the product market.

Similarly, if limited liability can instead efficiently resolve agency conflicts, then unlimited liability mandates will end up protecting small inefficient firms against entry. Carr \& Matthewson (1988) show theoretically that unlimited liability can act as such a rent-protection device, and document that data on eighteenth-century Scottish banks, nineteenth-century Massachusetts textile firms, and 1977 U.S. law firms (all businesses forced to operate with unlimited liability for shareholders or partners) are consistent with the rent-protection argument.

\section{Conclusion}

We document that harsh penalties for individual default have a long history but are not just a relic of the past. While nowadays a majority of countries ban the cruelest means of forcing compliance with the terms of financial contracts, individual debtors in many countries still find it difficult or outright impossible to walk away from their obligations. At an extreme, debt bondage still prevails today in some environments.

We also show that, while defaulting on personal and corporate debts has traditionally entailed dire consequences, limited liability is far from a recent institution. For thousands of years, merchants and, later, entrepreneurs and investors have attempted to limit their liabilities resulting from business transactions. Yet, today, even arms-length investors are not completely free from the threat that courts might decide to put their personal assets at the disposition of corporate creditors. In some countries, liability limits have remained (or become) illegal in specific economic sectors or for some types of debts.

In sum, a variety of financial contracts, with vastly different default penalties, have coexisted at various times. Against this background, a popular view of limited liability rules is that they are the result of societal preferences against excessive penalties. Granted, it may be that the desire to prevent perceived abuses by creditors sometimes leads legislators to invalidate "Faustian bargains"

\footnotetext{
${ }^{46}$ Note that banks would agree to lend to the entrant, because his threat to meet the monopolist's predatory pricing with a price war is credible so that no price war (and no resultant bankruptcy) would take place in equilibrium.
} 
or to ban particularly harsh contractual arrangements. A large number of theoretical and empirical papers, however, demonstrate that there are many other reasons why the contracting parties or society as a whole may be better off when the parties have their hands tied by the legal system. In other cases still, it is socially more efficient if parties can freely choose the penalty regime. The papers we discuss strongly suggest that limited liability often emerged when, in the absence of clear limits on economic agents' liability, the development of some economic activities might have been thwarted. Viewing the institution from this perspective of optimal legal system design allows us to better understand the current debate on it.

While the vast literature reviewed in the present paper deals extensively with contracting parties' optimal choice of a liability regime and with the impact of judicial liability rules on the welfare of economic agents, it also leaves some major questions unanswered. For example, very few papers so far have tackled the quantitative aspects of liability rules. Hence, there is no obvious estimate of the potential impact of unlimited liability mandates on the rates of return required by shareholders, on equity-holding patterns, or on stock market development. Quantitative answers to such questions, however, would help assess the magnitude of any downside to lifting the corporate veil in some industries or for specific types of debts. Likewise, while various papers show that harsh penalties may be optimal in some financial contracts, relatively little work has focused on whether the optimal penalty should be financial or, instead, non-monetary in nature. Yet, it is a priori unclear why a purely non-monetary penalty, in which the creditor gets nothing, might be better than a monetary one in deterring or remedying default.

Finally, the evidence mustered in this paper suggests that, rather than a response to societal preferences, default penalties are a response to the needs of the contracting parties. Examples include the ability to monitor the borrower's action, the likelihood of external shocks, the typical borrower's human capital stock, etc. Limits on contractual freedom have also been used as a political tool, to substitute for a weak social security net, encourage investment and entrepreneurship, and generally provide incentives for increased economic activity. A general model that answers which contract and liability rules are optimal under what circumstances is, to the best of our knowledge, still missing. We look forward to seeing answers to these questions. 


\section{References}

Adler, B., Polak, B., \& Schwartz, A. (2000). Regulating consumer bankruptcy: A theoretical inquiry. Journal of Legal Studies, 29(2), 585-613.

Agarwal, S., Liu, C., \& Mielnicki, L. (2003). Exemption laws and consumer deliquency and bankruptcy behavior: An empirical analysis of credit card data. The Quaterly Review of Economics and Finance, 43, 273-89.

Aghion, P. \& Hermalin, B. (1990). Legal restrictions on private contracts can enhance efficiency. Journal of Law, Economics and Organization, 6(2), 381-409.

Araujo, A. P., Madeiro, P., \& Pascoa, M. O. (1998). Incomplete markets, continuum of states and default. Economic Theory, 11, 205-13.

Araujo, A. P. \& Pascoa, M. O. (2002). Bankruptcy in a model of unsecured claims. Economic Theory, 20, $455-81$.

Armstrong, V. \& Riddick, L. (2003). A comparison of bankruptcy laws among G-7 nations. Working Paper, American University.

Athreya, K. (2005). Equilibrium models of personal bankruptcy: A survey. Federal Reserve Bank of Richmond Economic Quaterly, 91(2), 73-98.

Athreya, K. B. (2002). Welfare implications of the bankruptcy reform act of 1999. Journal of Monetary Economics, 49, 1567-95.

Aumann, R. J. \& Maschler, M. (1985). Game-theoretic analysis of a bankrutpcy problem from the Talmud. Journal of Economic Theory, 36, 195-213.

Ayotte, K. (2007). Bankruptcy and entrepreneurship: The value of a fresh start. Journal of Law, Economics and Organization, $23(1)$, forthcoming.

Babington, A. (1971). The English Bastille: A History of Newgate Gaol and Prison Conditions in Britain 1188-1902. New York: St. Martin's Press.

Bar-Gill, O. (2004). Seduction by plastic. Northwestern University Law Review, 98, 1373-1434.

Basu, K. (1992). Limited liability and the existence of share tenancy. Journal of Development Economics, 38(1), 203-20.

Basu, K., Bell, C., \& Bose, P. (2000). Interlinkage, limited liability and strategic interaction. Journal of Economic Behavior and Organization, 42(4), 445-62.

Bebchuk, L. A. (2002). The ex-ante costs of violationg absolute priority in bankruptcy. Journal of Finance, $57,445-60$.

Bebchuk, L. A. \& Picker, R. C. (1993). Bankruptcy rules, managerial entrenchment and firm-specific human capital. John M. Olin Law and Economics Working Paper No.16 (Second Series), University of Chicago.

Berkovitch, E., Israel, R., \& Zender, J. F. (1997). An optimal bankruptcy law and firm-specific investments. European Economic Review, 41.

Berkovitch, E., Israel, R., \& Zender, J. F. (1998). The design of bankruptcy law: A case for management bias in bankruptcy reorganizations. Journal of Financial and Quantitative Analysis, 33(4), 441-64.

Berkowitz, J. \& Hynes, R. (1999). Bankruptcy exemptions and the market for mortgage loans. Journal of Law and Economics, 42(2), 809-30.

Berkowitz, J. \& White, M. J. (2004). Bankruptcy and small firms' access to credit. Rand Journal of Economics, 35(1), 69-84.

Besanko, D. \& Thakor, A. V. (1987a). Collateral and rationing: Sorting equilibria in monopolistic and competitive markets. International Economic Review, 28(3), 671-89. 
Besanko, D. \& Thakor, A. V. (1987b). Competitive equilibrium in the credit market under asymmetric information. Journal of Economic Theory, 42(1), 167-82.

Besta, E. \& Predelli, R. (1901). Gli statuti civili di Venezia anteriori al 1242. Nuovo Archivio Veneto, 1(1-2), 1-117 and 205-300.

Bester, H. (1985). Screening vs. rationing in credit markets with imperfect information. American Economic Review, 75(4), 850-5.

Bester, H. (1987). The role of collateral in credit markets with imperfect information. European Economic Review, 31(4), 887-99.

Bigus, J. \& Steiger, E.-M. (2002). When it pays to be honest: How a variable period of good conduct can improve incentives in personal bankruptcy proceedings. Paper presented at the 2002 Meeting of the American Law and Economics Association, May.

Bigus, J. \& Steiger, E.-M. (2003). Variable Wohlverhaltensperiode als anreizkompatibles Instrument des Verbraucherinsolvenzverfahrens. Zeitschrift fuer Betriebswirtschaft, 73(11), 1197-219.

Boileau, J. (1945). La societé en commandite. Unpublished thesis, Ecole des Hautes Etudes Commerciales, Montreal.

Bolton, P. \& Rosenthal, H. (2002). Political intervention in debt contracts. Journal of Political Economy, $110(5), 1103-34$.

Boyd, J. \& Smith, B. (1994). How good are standard debt contracts? Stochastic vs. non-stochastic monitoring in a costly state verification environment. Journal of Business, 67(4), 539-61.

Brandt, L. \& Hosios, A. J. (1996). Credit, incentives, and reputation: A hedonic analysis of contractual wage profiles. Journal of Political Economy, 104(6), 1172-1226.

Brinig, M. F. \& Buckley, F. (1996). The market for deadbeats. Journal of Legal Studies, 25, 201-32.

Brockman, C. (2004). Bankruptcy - A fresh start?. New Law Journal, 154(7122), 488-89.

Brown, M. \& Zehnder, C. (2005). Credit registeries, relationship banking and loan requirement. IERE Working Paper No.249, University of Zurich, May.

Brown, R. L. (1996). A History of the Fleet Prison, London: The Anatomy of the Fleet. Edwin Mellen Press, London.

Bulow, J. \& Rogoff, K. (1989). Sovereign debt: Is to forgive to forget. American Economic Review, 79(1), $43-50$.

Calder, L. (2001). Financing the American Dream. Princeton University Press.

Carmichael, H. L. (1989). Self-enforcing contracts, shirking, and life cycle incentives. Journal of Economic Perspectives, 3(4), 65-83.

Carney, W. J. (1999). Limited liability. In Encyclopedia of Law and Economics. B. Bouckaert and G. De Gesst Eds. Edward Elgar: Northampton, Massachusetts, http://encyclo.findlaw.com/5620book.pdf.

Carney, W. J. (2001). Abolishing veil piercing. Journal of Corporation Law, 26, 479-535.

Carr, J. L. \& Matthewson, G. F. (1988). Unlimited liability as a barrier to entry. Journal of Political Economy, 96(4), 766-843.

Chatterjee, H. N. (1971). The Law of Debt in Ancient India. Calcutta, India: Calcutta Sanskrit College. Research Series 75.

Chatterjee, S., Corbae, D., Nakajima, M., \& Rios-Rull, J.-V. (2005a). A quantitative theory of unsecured consumer credit with risk of default. Working Paper 05-18, Federal Reserve Bank of Philadelphia, August. 
Chatterjee, S., Corbae, D., \& Rios-Rull, J.-V. (2005b). Credit scoring and competitive pricing of default risk. Mimeo, Federal Reserve Bank of Philadelphia, April.

Christianson, S. (1996). A Land Of Bondage with Liberty for Some: 500 Years of Imprisonment in America. Northeastern University Press, Boston.

Cizakca, M. (1996). A Comparative Evolution of Business Partnerships: The Islamic World \& Europe. New York: Brill.

Coco, G. (2000). On the use of collateral. Journal of Economic Surveys, 14 (2), 191-214.

Conklin, J. (1998). The theory of sovereign debt and Spain under Philip II. Journal of Political Economy, $106(3), 483-513$.

Cordella, T. \& Levy-Yeyati, E. (2003). Limits of conditionality in poverty reduction programs. Journal of Financial Intermediation, 12(4), 300-30.

Demougin, D. M. \& Fluet, C.-D. (2001). Monitoring vs. incentives. European Economic Review, 45(9), $1741-64$.

Demougin, D. M. \& Garvie, D. A. (1991). Contractual design with correlated information under limited liability. Rand Journal of Economics, 22(4), 477-89.

di Martino, P. (2005). Approaching disaster: Personal bankruptcy legislation in Italy and England, c.18801939. Business History, 47(1), 23-43.

Diamond, D. W. (1984). Financial intermediation and delegated monitoring. Review of Economic Studies, $51(3), 393-414$.

Diamond, D. W. (1989). Reputation acquisition in debt markets. Journal of Political Economy, 97(4), $828-62$.

Dionne, G. \& Spaeter, S. (2003). Environmental risk and extended liability: The case of green technologies. Journal of Public Economics, 87(4), 1025-60.

Dubey, P., Geanakoplos, J., \& Shubik, M. (1990). Default and eficiency in a general equilibrium model with incomplete markets. Cowles Foundation Discussion Paper No. 773.

Dubey, P., Geanakoplos, J., \& Shubik, M. (2005). Default and punishment in general equilibrium. Econometrica, 73(1), 1-37.

Easterbrook, F. H. \& Fishel, D. R. (1985). Limited liability and the corporation. University of Chicago Law Review, 52, 89-117.

Eberhart, A. \& Senbet, L. W. (1993). Absolute priority rule violations and risk incentives for financially distressed firms. Financial Management, 22(3), 101-16.

Efrat, R. (1998). The moral appeal of personal bankruptcy. Whittier Law Review, 20(November), 141-67.

Efrat, R. (2002). Global trends in personal bankruptcy. American Bankruptcy Law Journal, 76, 81-109.

Elul, R. \& Subramanian, N. (2002). Forum-shopping and personal bankruptcy. Journal of Financial Services Research, 21(3), 233-55.

English, W. B. (1996). Understanding the costs of sovereign default: American state debts in the 1840's. American Economic Review, 86(1), 259-75.

Erler, A., Kaufmann, E., \& Stammler, W. (1971). Handwoerterbuch zur Deutschen Rechtsgeschichte. Berlin: Erich Schmidt Verlag.

Esty, B. C. (1998). The impact of contingent liability on commercial bank risk taking. Journal of Financial Economics, 47(2), 189-218.

Evans, L. T. \& Quigley, N. C. (1995). Shareholder liability regimes, principal-agent relationships and banking industry performance. Journal of Law and Economics, 38(2), 497-520. 
Fan, W. \& White, M. J. (2003). Personal bankruptcy and the level of entrepreneurial activity. Journal of Law and Economics, 46(2), 543-67.

Fay, S., Hurst, E., \& White, M. J. (2002). The household bankruptcy decision. American Economic Review, 92(3), 706-18.

Filer, L. H. \& Fisher, J. D. (2005). The consumption effects associated with filing for personal bankruptcy. Southern Economic Journal, 71(4), 837-54.

Fluck, Z., Garrison, K., \& Myers, S. (2005). Venture capital: An experiment in computational corporate finance. NBER Working Paper No.11624, November.

Franks, J. \& Sussman, O. (2005). Financial innovations and corporate bankruptcy. Journal of Financial Intermediation, $14(3), 283-317$.

Fulghieri, P. \& Nagarajan, S. (1996). On the strategic role of high leverage in entry deterrence. Journal of Banking and Finance, 20(1), 1-23.

Gale, D. \& Hellwig, M. (1985). Incentive-compatible debt contracts: The one-period problem. Review of Economic Studies, 52(4), 647-63.

Gertner, R. \& Scharfstein, D. (1991). A theory of workouts and the effects of reorganization law. Journal of Finance, 46(4), 1189-222.

Ghatak, M. \& Pandey, P. (2000). Contract choice in agriculture with joint moral hazard in effort and risk. Journal of Development Economics, 63(2), 303-26.

Goodman, P. (1993). The emergence of homestead exemption in the United States: Accomodation and resistance to the market revolution, 1840-1880. The Journal of American History, 80(2), 470-98.

Graver, H. P. (1997). Consumer bankruptcy: A right or a privilege? The role of the courts in establishing moral standards of economic conduct. Journal of Consumer Policy, 20, 161-77.

Green, R. C. (1984). Investment incentives, debt, and warrants. Journal of Financial Economics, 13, $115-136$.

Gropp, R., Scholz, J., \& White, M. J. (1997). Personal bankruptcy and credit supply and demand. Quarterly Journal of Economics, 112(1), 217-51.

Gross, D. B. \& Souleles, N. S. (2002). An empirical analysis of personal bankruptcy and delinquency. Review of Financial Studies, 15(1), 319-47.

Grossman, P. Z. (1995). The market for share of companies with unlimited liability: The case of American Express. Journal of Legal Studies, 24(1), 63-85.

Grossman, R. S. (2001). Double liability and bank risk-taking. Journal of Money, Credit and Banking, $33(2), 143-59$.

Grubb, F. (2003). Babes in bondage - Parental selling of children to finance family migration: The case of German migration to North America, 1720-1820. Working Paper 2003-04, Department of Economics, University of Delaware, January.

Halpern, P., Turnbull, S., \& Trebilcock, M. (1980). An economic analysis of limited liability. University of Toronto Law Journal, 30, 117.

Han, S. \& Li, W. (2004). Fresh start or head start? The effects of filing for personal bankruptcy on the labor supply. Federal Reserve Bank of Philadelphia Working Paper No. 04-5.

Hansmann, H. \& Kraakman, R. H. (1991). Toward unlimited shareholder liability for corporate torts. Yale Law Journal, 100(7), 1879-1934.

Hansmann, H. \& Kraakman, R. H. (2003). The end of history for corporate law. In Gordon, J. \& Roe, M. (Eds.), Are Corporate Governance Systems Converging? University of Chicago Press. 
Hart, O. (2000). Different approaches to bankruptcy. Discussion Paper No. 1923, Harvard Institute of Economic Research, September.

Hart, O. \& Moore, J. (1994). A theory of debt based on the inalienability of human capital. Quarterly Journal of Economics, 109(4), 841-79.

Hart, O. \& Moore, J. (1998). Default and renegotiation: A dynamic model of debt. Quarterly Journal of Economics, 113(1), 1-41.

Hickson, C. \& Turner, J. (2003). The trading of unlimited liability bank shares in nineteenth-century Ireland: The Bagehot hypothesis. Journal of Economic History, 63(4), 459-76.

Holzhammer, R. (1996). Oesterreichisches Insolvenzrecht, Konkurs und Ausgleich. Springer Verlag.

Hoover, C. B. (1925). The sea loan in Genoa in the twelfth century. Quarterly Journal of Economics, 40(3), $495-529$.

Horvath, M. T. \& Woywode, M. J. (2005). Entrepreneurs and the choice of limited liability. Journal of Institutional and Theoretical Economics, 161, Forthcoming.

Hynes, R. \& Posner, E. A. (2002). The law and economics of consumer finance. American Law and Economics Review, 4(1), 168-207.

Hynes, R. M., Malani, A., \& Posner, E. A. (2004). The political economy of property exemption laws. Journal of Law and Economics, 47(1), 19-43.

Innes, R. T. (1990). Limited liability and incentive contracting with ex-ante action choices. Journal of Economic Theory, 52(1), 45-67.

Jensen, M. C. \& Meckling, W. H. (1976). Theory of the firm: Managerial behavior, agency costs and ownership structure. Journal of Financial Economics, 3(4), 305-60.

Jeweler, R. (2005). The "bankruptcy abuse prevention and consumer protection act of 2005," S. 256, in the 109th Congress. CRS Report for the Congress, RL 32765, Congressional Research Service, The Library of Congress.

Johns, R. C. (1910). Babylonian law. In Encyclopedia Britannica. Reproduced in the Yale Law School Avalon Project [http://www.yale.edu/lawweb/avalon/medieval/hammenu.htm].

Kalay, A. \& Zender, J. F. (1997). Bankruptcy, warrants, and state-contingent changes in the ownership of control. Journal of Financial Intermediation, 6(4), 347-79.

Kane, E. J. \& Wilson, B. K. (1998). A contracting-theory interpretation of the origins of federal deposit insurance. Journal of Money, Credit and Banking, 30(3), 573-95.

Karpoff, J. M., Lott, J. R., \& Rankine, G. (1998). Environmental violations, legal penalties and reputation costs. John M. Olin Law and Economics Working Paper No. 71, University of Chicago, October.

Kessler, A. D. (2003). Limited liability in context: Lessons from the French origins of the American limited partnership. Journal of Legal Studies, 32(2), 511-48.

Kilborn, J. J. (2003). The innovative German approach to consumer debt relief: Revolutionary changes in German law, and surprising lessons for the U.S.. Northwestern Journal of International Law and Business, $24(3), 1-46$.

Kilborn, J. J. (2005). La responsabilisation de l'économie: What the United States can learn from the new french law on consumer overindebtedness. Michigan Journal of International Law, 26, 619-71.

Kilborn, J. J. (2006a). Continuity, change, and innovation in emerging consumer bankruptcy systems: Belgium and Luxembourg. American Bankruptcy Institute Law Review, 14, forthcoming.

Kilborn, J. J. (2006b). The hidden life of consumer bankruptcy reform: Danger signs for the new U.S. law from unexpected parallels in the Netherlands. Vanderbilt Journal of Transnational Law, 39(1), forthcoming. 
Kilpi, J. (1998). The Ethics of Bankruptcy. Routledge, New York.

Kim, S. K. (1997). Limited liability and bonus contracts. Journal of Economics and Management Strategy, $6(4), 899-913$.

Kocherlakota, N. R. (1996). Implications of efficient risk sharing without commitment. Review of Economic Studies, 63(4), 595-609.

Koesters, W., Paul, S., \& Stein, S. (2004). An economic analysis of the EU commission's proposal for a new consumer credit directive: Offering consumers more protection or restricting their options. Intereconomics, 39(3), S84-97.

Kohn, M. (1999a). The capital market before 1600. Working Paper No. 99-06, Department of Economics, Dartmouth College, February.

Kohn, M. (1999b). Merchant banking in the medieval and early modern economy. Working Paper No. 99-05, Department of Economics, Dartmouth College, February.

Kowalewski, K. (2000). Personal bankruptcy: A literature review. CBO Working Paper.

Lacker, J. M. (2001). Collateralized debt as the optimal contract. Review of Economic Dynamics, 4(4), $842-59$.

Laffont, J.-J. \& Matoussi, M. S. (1995). Moral hazard, financial constraints and sharecropping in Eloulja. Review of Economic Studies, 62(3), 381-99.

Lawarrée, J. P. \& van Audenrode, M. (1996). Optimal contract, imperfect output observation, and limited liability. Journal of Economic Theory, 71(2), 514-31.

Lehnert, A. \& Maki, D. M. (2005). Consumption, debt and portfolio choice: Testing the effects of bankruptcy law. Working Paper, Board of Governors of the Federal Reverve System, March.

Lewis, T. R. \& Sappington, D. E. (1997). Information management in incentive problems. Journal of Political Economy, 105(4), 796-821.

Lin, E. Y. \& White, M. J. (2001). Bankruptcy and the market for mortgage and home improvement loans. Journal of Urban Economics, 50(1), 138-62.

Livermore, S. (1935). Unlimited liability in early American corporations. Journal of Political Economy, $43(5), 674-87$.

Livshits, I., McGee, J., \& Tertilt, M. (2005). Accouting for the rise in consumer bankruptcies. Working Paper, University of Western Ontario.

Longhofer, S. D. (1997). Absolute priority rules violations, credit rationing, and efficiency. Journal of Financial Intermediation, 6(3), 249-67.

Macey, J. \& Miller, G. P. (1992). Double liability of bank shareholders: History and implications. Wake Forest Law Review, 27, 31-62.

Maitland, F. (1904). Trust and the corporation. Zeitschrift fuer das Privat- und Oeffentliche Recht, 32.

Mann, B. H. (2003). Republic of Debtors: Bankruptcy in the Age of American Independence. Harvard University Press, Cambridge, MA.

Manne, H. G. (1967). Our two economic systems: Law and Economics. Virginia Law Review, 53(2), 259-84.

Martin, N. (2005). The role of history and culture in developing bankruptcy and insolvency systems: The perils of legal transplantation. Boston College International and Comparative Law Review, 28(1), $1-77$.

McGregor, S., Klingander, B., \& Lown, J. (2001). Comparative analysis of Canadian, American and Swedish bankruptcy policy: Why do governments legislate consumer debt. International Journal of Consumer Studies, 25(3), 208-227. 
Mirrlees, J. (1976). The optimal structure of incentives and authority within an organization. Bell Journal of Economics, 7(1), 105-31.

Muldrew, C. (1993). Credit and the courts: Debt litigation in a seventeenth-century urban community. Economic History Review, 46(1), 23-38.

Muro, S. A. (2005). Deciding on an efficient involuntary bankruptcy filing petition rule. Cornell Law School LL.M. Working Paper Series, Paper 6-2005, BEPress.

Musto, D. K. (2004). What happens when information leaves a market? Evidence from post-bankruptcy consumers. Journal of Business, 77(4), 725-48.

Niemi-Kiesilainen, J. (1997). Changing directions in consumer bankruptcy law and practice in Europe and the U.S.A.. Journal of Consumer Policy, 20, 133-42.

Noe, T. N. \& Smith, S. D. (1997). The buck stops where? The role of limited liability in economics. Federal Reserve Bank of Atlanta Economic Review, 82(1), 46-56.

OECD (1998). Statistical Compendium 1998-2 (CD-ROM). Paris: Organization for Economic Co-operation and Development.

Outhwaite, R. (1968). The trials of foreign borrowing: the English crown and the Antwerp money market in the mid-sixteenth century. Economic History Review, 19(2), 289-305. 2nd series.

Palomino, F. \& Pratt, A. (1999). Risk taking and optimal contracts for money managers. Working Paper, CentER at Tilburg University and CEPR, February.

Pandey, P. (2004). Effects of technology on incentive design of share contracts. American Economic Review, 94(4), 1152-68.

Patterson, M. \& Reiffen, D. (1990). The effect of the Bubble Act on the market for joint stock shares. Journal of Economic History, 50(1), 163-71.

Peare, C. (1956). William Penn: A Biography. The University of Michigan Press, Ann Arbor, MI.

Pitchford, R. (1995). How liable should a lender be? The case of judgment-proof firms and environmental risk. The American Economic Review, 85(5), 1171-86.

Pomykala, J. (1997). Bankruptcy reform. Regulation, 20(4), 41-49.

Pontani, M. (2004). Pre-bankruptcy crimes and entrepreneurial behavior: Some insights from Italian and American bankruptcy laws. German Working Papers in Law and Economics, Year 2004, Paper 14, BEPress.

Posner, E. A. (1995). Contract law in the welfare state: A defense of the unconscionablility doctrine, usury laws, and related limitations on the freedom to contract. Journal of Legal Studies, 24(2), 283-319.

Povel, P. (1999). Optimal 'soft' or 'tough' bankruptcy procedures. Journal of Law, Economics and Organization, 15(3), 659-84.

Pugh, R. B. (1968). Imprisonment in Medieval England. Cambridge University Press, London.

Ray, D. \& Singh, N. (2001). Limited liability, contractual choice, and the tenancy ladder. Journal of Development Economics, 66(1), 289-303.

Rea, S. A. (1984). Arm-breaking, consumer credit and personal bankruptcy. Economic Inquiry, 22(2), $188-208$.

Resnicoff, S. H. (1998). Viewpoint: A Jewish law perspective on the propriety of discharging personal debts. Bankruptcy Court Decisions: Weekly News 85 Comment, February 3, A3-4.

Robe, M. A. (2001). What can we learn from simulating a standard agency model. Economics Letters, $73(2), 137-46$. 
Robe, M. A. \& Michel, P.-A. (2000). De l'optimalité de la responsabilité limitée dans les contrats financiers. In Jurion, B. \& Pestieau, P. (Eds.), Finances Publiques, Finances Privées, pp. 247-70. Brussels: Editions Luc Pire.

Rosenberg, J. \& Weiss, A. (2001). Clean slate proclamations, the Jubilee, and anti-monopoly laws. Working Paper, Bar-Ilan University.

Sappington, D. (1991). Incentives in principal agent relationships. Journal of Economic Perspectives, 5(2), $45-66$.

Sappington, D. E. (1983). Limited liability contracts between principal and agent. Journal of Economic Theory, 29(1), 1-21.

Sartre, P.-D. \& Li, W. (2006). The macroeconomics of U.S. consumer bankruptcy choice: Chapter 7 or Chapter 13. Journal of Monetary Economics, forthcoming.

Scheppach, M. (1991). Las Siete Partidas: Entstehungs- und Wirkungsgeschichte. Ph.D. Dissertation, Universitaet Kiel, Centaurus-Verlags GmbH, Pfaffenweiler.

Schiller, K. \& Luebben, A. (1880). Mittelniederdeutsches Woerterbuch: Fuenfter Band U-Z. Verlag von J. Kuehtmann's Buchhandlung.

Schinski, M. \& Mullineaux, D. (1995). The impact of the Federal Reserve's source of strength policy on bank holding companies. Quarterly Review of Economics and Finance, 35(0), 483-96.

Schwartz, A. (2005). A normative theory of business bankruptcy. Virginia Law Review, 91(1), 1199-265.

Sengupta, K. (1997). Limited liability, moral hazard and share tenancy. Journal of Development Economics, 52(2), 393-407.

Seniawski, B. L. (2001). Riba today: Social equity, the economy, and doing business under Islamic law. Columbia Journal of Transnational Law, 39, 701.

Shetty, S. (1988). Limited liability, wealth differences and tenancy contracts in agrarian economies. Journal of Development Economics, 29(1), 1-22.

Sinoué, G. (2002). L'Ambassadrice. Paris: Calmann-Lévy.

Skeel, Jr., D. A. (2001). Debt's Dominion: A History of Bankruptcy Bankruptcy Law in America. Princeton University Press, Princeton, NJ.

Smart, M. (1996). On limited liability and the development of capital markets: An historical analysis. Working Paper, Institute for Policy Analysis, University of Toronto, June.

Smith, A. E. (1947). Colonists in Bondage: White Servitude and Convict Labor in America, 1607-1776. University of North Carolina Press.

Steiger, E.-M. (2005a). Ex-ante vs. ex-post efficiency in personal bankruptcy proceedings. Working Paper, Humboldt Universitaet zu Berlin, May.

Steiger, E.-M. (2005b). Personal Bankrutpcy Law: An Economic Analysis. Deutscher Universitaets-Verlag, Gabler Edition Wissenschaft, Wiesbaden, zugl. Ph.D. Dissertation, Universitaet Hamburg, 2004.

Suen, W. (1995). Risk avoidance under limited liability. Journal of Economic Theory, 65(2), 627-34.

Tabb, C. J. (1995). The history of the bankruptcy laws in the United States. American Bankruptcy Institute Law Review, 3, 5-51.

Tabb, C. J. (2005). Lessons from the globalization of consumer bankruptcy. Illinois Law and Economics Working Paper No. LE05-013.

Thakor, A. V. (1996). The design of financial systems: An overview. Journal of Banking and Finance, 20(5), $917-48$.

t'Kint, F. (1991). Sûretés et Principes Généraux du Droit de Poursuite des Créanciers. Bruxelles: Larcier. 
Townsend, R. M. (1979). Optimal contracts and competitive markets with costly state verification. Journal of Economic Theory, 21(2), 265-93.

Tung, F. (1999). Taking future claims seriously: Future claims and successor liability in bankruptcy. Case Western Reserve Law Review, 49(3), 435.

U.S. Congress (1999). Biographical directory [http://bioguide.congress.gov]..

Vigneron, R. (1998). Cours de Droit Romain. Presses de l'Université de Liège, Liège.

Wang, H.-J. \& White, M. J. (2000). An optimal personal bankruptcy system and proposed reforms. Journal of Legal Studies, 31(1), 255-86.

Weidenmier, M. D. (2005). Gunboats, reputation, and sovereign repayment: Lessons from the Southern Confederacy. Journal of International Economics, 66(2), 407-22.

Weinstein, M. I. (2003). Share price changes and the arrival of limited liability in California. Journal of Legal Studies, 32(1), 1-25.

Weinstein, M. I. (2005). Limited liability in California 1928-1931: It's the lawyers. American Law and Economics Review, 7(2), 439-83.

Welch, K. D. (1995). Bankruptcy, debtors' prison, and collateral in optimal debt contracts. Working Paper, University of Chicago, December.

West, M. D. (2003). Dying to get out of debt: Consumer insolvency law and suicide in Japan. Michigan Law and Economics Research Paper No. 03-015, December.

White, M. J. (1996). The costs of corporate bankruptcy: A U.S.-European comparison. In Bhandari, J. S. \& Weiss, L. A. (Eds.), Corporate Bankruptcy: Economic and Legal Perspectives, pp. 467-500. Cambridge University Press, London.

White, M. J. (1998a). Why don't more households file for bankruptcy. Journal of Law, Economics, and Organization, 14(2), 205-31.

White, M. J. (1998b). Why it pays to file for bankruptcy: A critical look at the incentives under U.S. personal bankruptcy law and a proposal for change. University of Chicago Law Review, 65(3), 685.

White, M. J. (2005a). Economic analysis of corporate and personal bankruptcy law. NBER Working Paper No. 11536, August.

White, M. J. (2005b). A general model of personal bankruptcy: Insurance, work effort, opportunism, and the efficiency of the fresh start. Working Paper, University of California at San Diego, March.

Wiggins, S. N. \& Ringleb, A. H. (1992). Adverse selection and long-term hazards: The choice between contract and mandatory liability rules. Journal of Legal Studies, 21(1), 189-215.

Winton, A. (1993). Limitation of liability and the ownership structure of the firm. Journal of Finance, 48(2), 487-512.

Wohlschlegel, A. (2003). Bankruptcy law and financial structure: The impact of managerial incentives. Working Paper, Universitaet Heidelberg, May.

Woodward, S. (1985). Limited liability in the theory of the firm. Journal of Institutional and Theoretical Economics, 141(4), 601-11.

Wylen, S. (1996). The Jews in the Time of Jesus. Paulist Press.

Zaborowski, C. \& Zweifel, P. (1999). Getting out of debt: Garnishment of wage in whose interest?. European Journal of Law and Economics, 8, 207-230.

Zame, W. R. (1993). Efficiency and the role of default when security markets are incomplete. American Economic Review, 83(5), 1142-64.

Zhou, H. (1995). A Comparative Analysis of Bankruptcy Procedures and Substantive Mechanisms of Bankruptcy Law. Law Press Publication, China. 


\section{SFB 649 Discussion Paper Series 2006}

For a complete list of Discussion Papers published by the SFB 649, please visit http://sfb649.wiwi.hu-berlin.de.

001 "Calibration Risk for Exotic Options" by Kai Detlefsen and Wolfgang K. Härdle, January 2006.

002 "Calibration Design of Implied Volatility Surfaces" by Kai Detlefsen and Wolfgang K. Härdle, January 2006.

003 "On the Appropriateness of Inappropriate VaR Models" by Wolfgang Härdle, Zdeněk Hlávka and Gerhard Stahl, January 2006.

004 "Regional Labor Markets, Network Externalities and Migration: The Case of German Reunification" by Harald Uhlig, January/February 2006.

005 "British Interest Rate Convergence between the US and Europe: A Recursive Cointegration Analysis" by Enzo Weber, January 2006.

006 "A Combined Approach for Segment-Specific Analysis of Market Basket Data" by Yasemin Boztuğ and Thomas Reutterer, January 2006.

007 "Robust utility maximization in a stochastic factor model" by Daniel Hernández-Hernández and Alexander Schied, January 2006.

008 "Economic Growth of Agglomerations and Geographic Concentration of Industries - Evidence for Germany" by Kurt Geppert, Martin Gornig and Axel Werwatz, January 2006.

009 "Institutions, Bargaining Power and Labor Shares" by Benjamin Bental and Dominique Demougin, January 2006.

010 "Common Functional Principal Components" by Michal Benko, Wolfgang Härdle and Alois Kneip, Jauary 2006.

011 "VAR Modeling for Dynamic Semiparametric Factors of Volatility Strings" by Ralf Brüggemann, Wolfgang Härdle, Julius Mungo and Carsten Trenkler, February 2006.

012 "Bootstrapping Systems Cointegration Tests with a Prior Adjustment for Deterministic Terms" by Carsten Trenkler, February 2006.

013 "Penalties and Optimality in Financial Contracts: Taking Stock" by Michel A. Robe, Eva-Maria Steiger and Pierre-Armand Michel, February 2006.

SFB 649, Spandauer Straße 1, D-10178 Berlin

http:/ / sfb649.wiwi.hu-berlin.de 